Portland State University

PDXScholar

\title{
The sasswood ordeal of the west Atlantic tribes of Sierra Leone and Liberia: an ethnohistoriographic survey
}

Sarah Louise Davies

Portland State University

Follow this and additional works at: https://pdxscholar.library.pdx.edu/open_access_etds

Part of the African Studies Commons, and the Social and Cultural Anthropology Commons Let us know how access to this document benefits you.

\section{Recommended Citation}

Davies, Sarah Louise, "The sasswood ordeal of the west Atlantic tribes of Sierra Leone and Liberia: an ethnohistoriographic survey" (1973). Dissertations and Theses. Paper 1675.

https://doi.org/10.15760/etd.1674

This Thesis is brought to you for free and open access. It has been accepted for inclusion in Dissertations and Theses by an authorized administrator of PDXScholar. Please contact us if we can make this document more accessible: pdxscholar@pdx.edu. 
AN ABSTRACT OF THE THESIS OF Sarah Louise Davies for the Naster of Arts in Anthropology presented August 27, 1973.

Title: The Sasswood Ordeal of the West Atlantic Tribes of Sijexra Leone and Liberia: An Ethnohistoriographic Survey

APPROVED BY MEMBERS OF THE THESIS COMMITTEE:

John H. Atherton, Chairman'

Shirley M. Kennêfy

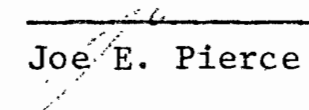

in

Inno Ukaejé

The sasswood ordeal of poison presents a divinatory ritual which has been used in criminal cases by the traditional African of: Sierra Leone and Liberia. For at least six hundred years, the peoples of these present countries have imposed this strjctest of ordeals on 
theix moral Eansgressors; and the piactice has survived, despite the protestations of nineteenth-century missionaries and the encroachnent of the western worid.

The investigation of the hiscorical evidence of the sasstrood oriden among the West Atlantic tribes of Africa has three basto purposes. First, because of the paucity of interpretive data on the sasswood orran, the primary purpose of the thesis has been to more cleariy dellactse ho moaning, characteristics, and functions of this poison ordeal as weil ais the swearing of oaths among the peoples of Sierra Leone and Iiberia by amalgamating historical and more contenporaneous evidence. To this end. the distribution of the ordeal was considered; and descriptions vere made of the various characteristics of the trait-comolex--the polson's action, the ritual and ceremonial aspects, the sasswood specialist, the accusations made in connection with the crdeal as well as indigenous myths of origin of the ordeal. Intraculturai correlations were then presented to demonstrate the interdigitation of the elements in a cuture In relation to the ordeal. Finaily, some functicns, other than the owvious guilt-determining aspect, were preserted to demonstrate the various ways in which it had been used historicaily.

A second purpose of this tîtesis was to demonstrate the intrinsically conseryative qualities of the ordeal as ais aspect of religion and law. By assessing the impact of specific historical influances fin the region of the west Atlantic tribes, such as Islan, colonialism, siavery, and urbanization, it was shown that no significat: change had been vitnessed througit the six-hundred-year period of the historical record. In conciuding this aspect, it was noted that certain "weaknesies" in the 
historical record--such ts its betro "piecemeal" and recorded only infrequentiy--caused probjems in finterpretiag what appeared to be an tntrinsically conservative nature of the sasswood ordeal.

A third purpose, related to the second, was the application and assessment of "ethnohistoriographic" temiques, that is, those specific methods of historical scholarship utilized by the ethnograpier in investigating past cultures. The limits of the use of the ethnohistoriographic techniques included observational bijas (which was readiiy accountable, dealing as it did with hyperbole), the preoccupation with "sensational" date (which provided disparaties, over-emphases in the historical record), as well as political motivations such that national prejudice frequentiy determined the "intergretation" placed on the ordeaj. In addtion, it was noted that because the sasswood oxdeay may be classified as "esoterica," the record for this practice was generally spotty; and this fact affected interpretations on the actual. change manifested in the trait-complex.

The main contribution made by this study has been to afford future readers with a composite and relatively complete source of information on one specific type of poison ordeal practiced among the West Atlantic tribes of Sierra Leone and Liberia. 
THE SASSWOOV OWDAE OT TWD WEST ATAITIC TRISES

\begin{abstract}
OF STERRA IEONE AND LIBERTA:
AN ETHUCHSTORIOGRAPHIC SURVEY
\end{abstract}

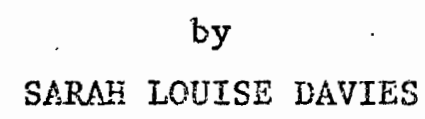

A thesis subnitted in partial fulfillment of the requirements for the degree of

MASTER OF ARTS

in

ANTHIROPOLOGY

Portland State Uiversity

1973 
For

Simon,

a brazen Jittle man who knows

and

M.H.,

his vigor, contagious intensity, and insatiable curiosity, his empathy and gentility 
TO THE OFFICE OF GRADUATE STUDIES AND RESEARCH:

The members of the Committee approve the thesis of Sarah Louise Davies presented August 27, 1973.
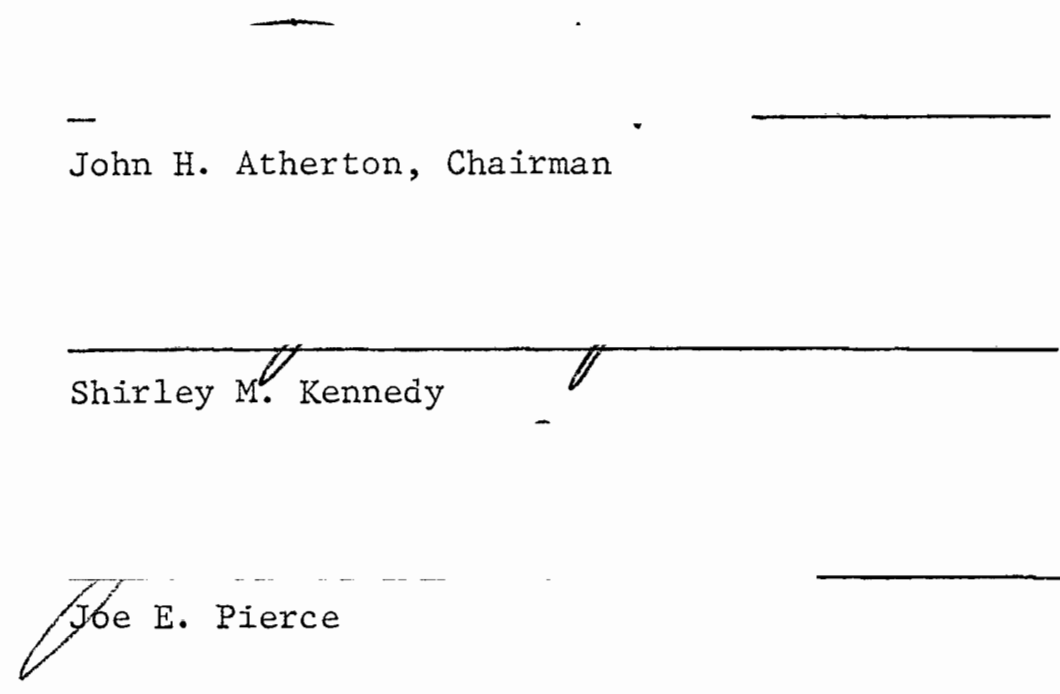

$\gamma$

APPROVED:

Inno Ukaeje

Thomas Newman, Head, Department of Anthropology

7 C C

David T. Clark, Dean, Graduate Studies and Research

December 28,1973 


\section{ACKNOWLEDGEMENTS}

Perhaps more than any one event, I would like to ackiowledge as the start of a11 this, 2:00 PM, September 28, 1965, and a.11 that occurred at that time (and after).

Special note and thanks should be given for the consistent kindness, care, and unflagging consideration given to me by friends at Fortland State University, especially Marilyn Peterson, Patt Lamb, Marilyn Couture, Bob Bogue, ard tous mes autres confréres.

To my $\mathrm{Ma}$ and $\mathrm{Pa}$, I can only say thank you for their persistent prodding and their moral support.

Finally, I should like to thank Dr. John Atherton for his academic support from the beginnings, and Ir. Daniel Scheans, for his humorsome sense of discipline. 
TABLE OF CONTENTS

PAGE

ACKNOWLEDGEMENTS . . . . . . . . . . . . . . . .

LIST OF FIGURES . . . . . . . . . . . . . . . . viii

CHAFTER

I INTRODUCTION . . . . . . . . . . . . . 1

Statement of Problem . . . . . . . . . 2

Theory ................... 6

Methodology . . . . . . . . . . . . 7

Historical Ethnography

Ethnohistoriography

Problems of Written Sources

Ora1 Tradition

The West Atlantic Tribes . . . . . . . . 15

Prospectus .................., 17

II THE PELATION OF LAW AND RELIGION . . . . . . . 19

Social Sanctions............... 19

Ritual ................... 23

Divination . . . . . . . . . . . . . . 24

Caths and ordeals . . . . . . . . . . 26

III THE SASSWOOD ORDEAL OF POISON . . . . . . . 34

Distribution and Names . . . . . . . . . 34

Operation of the ordeal . . . . . . . . . 37 
The poison.............. 40

The Sasswood Specialist . . . . . . . 43

The Accusers and the Accused ......... 44

Origin Myths .............. 48

Intracultural Correlations . . . . . . . . 52

Econonic Correlations

Social and Political Correlations

Socialization

Functions ...............

Legal Mechanism

Social Unifier

Equalizer of Social Status

Association with Slavery

Politics and "Police"

Education

IV HISTORICAL INFLUENCES AND THE MANIFESTATIONS

OF CHANGE . . . . . . . . . . . . 68

Culture Change and the Ordeal ....... 68

Historical Influences . . . . . . 72

Islam

Slavery

Western European Influences

Urbanization

v SUMARY AND CONCLUSIONS . . . . . . . . 91

summary . . . . . . . . . . 91

Conc1usions .................. 94

Ethnohistoriographic prosiens

Persistence and Charige in the Ordeal

Historical Influences

GeneraI Conciusions ........... 
Appendix A: Sumary of the Explorers to Sierra

Leone and Liberia, with Special

Reference to the Practice of the

Sasswood Ordeal . . . . . . . .

Appendix B: The Redwater Tria1: 1795 . . . . . 
LIST OF FICURES

FIGURE

PAGE

I The West Atlantic iribes 
CHAPTER I

INTRODUCTION 
CHAPTER I

INTRODUTTION

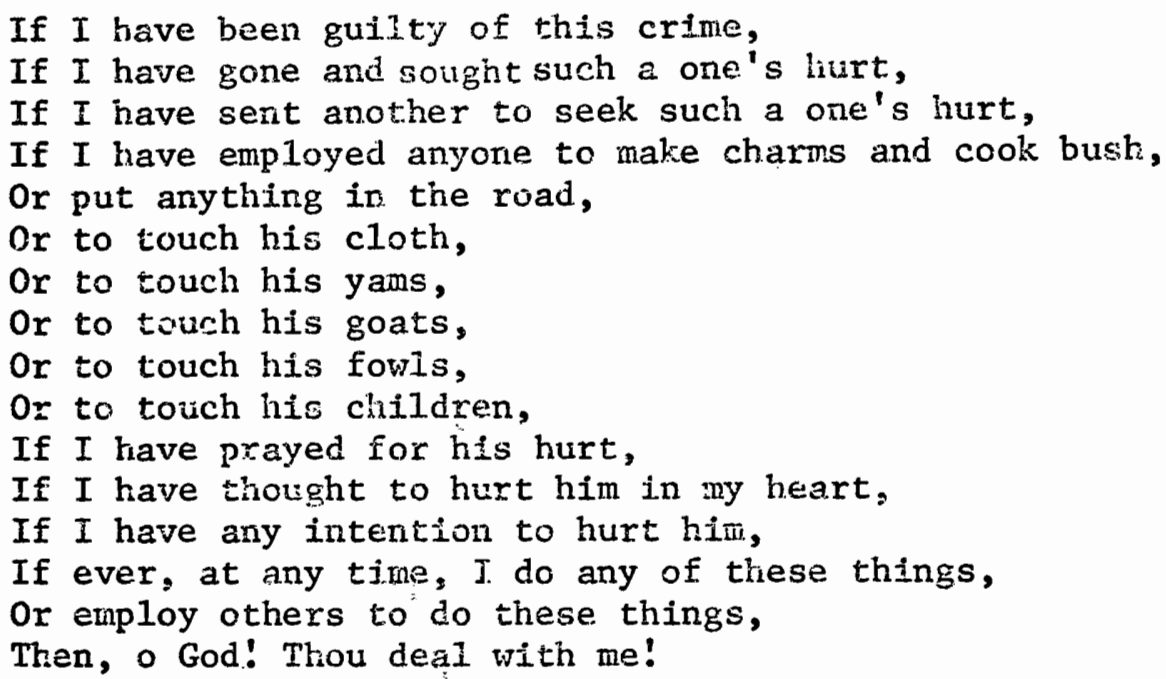

West African Oath ${ }^{1}$

An esteemed Senator, learned in the law, has called the liedetector test "twentieth century witchcraft," and in very nearly the same breath has demanded that his witnesses "swear to tell the truth, the whole truth, and nothing but the truth, so he1p you God." 2 In the first case, certain physiological responses such as pulse rate, respiration, and perspiration are measured to ascertain guilty knowledge or lying in the Indivioual when asked questions, sinee it is thought that these autonomic responses occur outside of himan self-control. In the

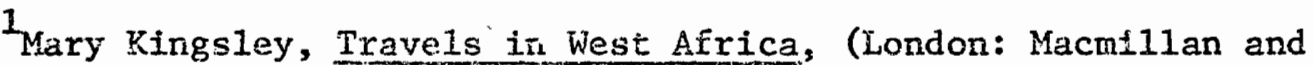
Company, 1897), ?. 465 .

${ }^{2}$ Senator Sam Ervin, Senate Select Comnirtee on Campaign Activities, June, 1973. 
second case, an ancient ritual of taking ar oath on a sacred object, such as the Bible, is being performed, so that if an untruth is tcld, God w111 seek His appropriate revenge. Yet the effect is the same in both cases: the guilty wili be exposed, one way or the others through the apparent actions of extra-human controls.

These practices are universals, though they cone in different guises; and their aspects among the West Atlantic tribes of Africa ${ }^{3}$ wil: be presented in the thesis, not as twentiath-century (or seventeenthcentury or fifteenth-century) witchcraft, but as long-standing, currently viable practices, vital to the societies of that region in many ways. External sanctions and judgments are manifested through the actions of the supernatural in the ordeals and oaths performed by the indigens of Sierra leone and Liberia. For at least six hundred years, the peoplas of these present countries have imposed one of the strictest of ordeals-the sasswood ordeal of poison--on their moral transgressors; and the practice has survived, despite the protestations of nineteenti-century aisstonaries and the encroachment of the western world. That this practice has survived at ail would attest to its aileged success and efficacy in the view of those who utilize it.

\section{STATEMENT OF PROBLEI}

The investigation of the nistorjcal evidence of the sasswood ordeal among the West Atlantic tribes of Africa has three basic purposes.

1. Because of the palicjty of interpretive data on the sasswood ${ }^{3}$ See page 15. 
ordeal and oath-swearing, the primary purpose of this thesis will be to more clearly delineate the meaning, characteristics, and functions of this poison ordeal as well as the swearing of oathe amorig the peoples of Sierra Leone and Liberia." By amalgaaling historical and more contemporary evidence from these areas, it will be possible to afford a more complete picture of the practices than has been previously provided. In addition, the relationship of these legal-yeligious divinatory procedures to the operation of the whole of the culture will be explored.

2. A second purpose of this thesis will be to demonstrate the intrinsically conservative qualities of the ordeal and oaths as aspects of religion and 1 aw. By assessing specific historical influerces in the region of the West Atlantic tribes, suct as Islam and colonialism, It will be shown that no signficant change has been witnessed through the six-hundred-year period of the historical record. This fact, it w111 be demonstrated, might be related to certain deficiencies in the historical record which might give the appearance of the lack of change. However, it will be possible to conclude that the basic tenacity and adaptability of the ordeal and oath complex is evident through time", substantiating the existence of a highly persistent trait-complez.

3. A third purpose will be the application and assessment of "ethnohistoriographic" techniques, that is, those specific methods of historical scholarship utilized by the ethnographer in investigating past cultures. The principal research source in the case of the sasswood ordeal has been historical, written documents. There are 1imits to the use of this methodology which shall be discussed in the section on "Methodology" in this Introduction. 
One of the principal assumptions to keep in mind in reading this thesis lies in the difference between a trait and a trait-complex. Trafts and trait-complexes are "1deal" material for an historical study in that "the historical viewpoint focuses attertion on unique, or spectfic, objects and events in time and in place. In echnology, it deals with cultural elements as they have actually existed ... recording their chronological and spatial story." 4 The minimum significant unit of culture capable of belng isolated in time and in space is called a trait, and interrelated traits are grouped into a trait-complex. 5 For this reason of its specificity, the sasswood ordeal and oath-swearing were regarded concurrently as linked trait-complexes. Oath-swearing and ordeals could have been treated independently as a trait-complex, for each, as an fitem of cultural behavior, can be broken into further constituent elements or traits. Because of the co-incidence of these two trait-complexes among the West Atlantic tribes, however, they were considered as a single trait-complex.

There were two main reasons for having chosen the subject of a spectfic kind of ordeal for the present study. First of all, in approaching any tople historically, one is faced with a distinct problein: what is of interest to the present reader and researcher was not necessarily of comparable interest to the earlier recorder of events. Where the present author would find the etiology, function, and Ideo1ogy of legal-religious cultiral practices of prime importance and

${ }^{4}$ Felix Keesing, Ciltural Anthropology (Nen York: Holt, Rinehart, and Winstion, 1958), $\Gamma .145$.

${ }^{5}$ Ibia. 
interest, the early observer of West African religions and laws would more likely ba attracted by, and subsequently record the sensactonal as he came across it: the sacrifices, the elaborate rituals, the cannibal1sm, and the ordeals. These were not everyday occurences in the western European explorer's life, and they therefore caught his notice. He was content to record what he saw, too, through his own "cultural eyes," and this limited the accurate description of what he did, in fact, perceive. Discrepancles among the reports are wltness to this fact. These matters, however, are subject to discussion in a later section of this chapter. Oaths and ordeals were chosen for diachronic study because of their "sensational" quality, which meant historicaliy that they were recorded, and for theix appeal to the author in terms of functional considerations and the relation to the persistence of the trait-complex. The second motivation for choosing the topic of ordeals lies in the fact that they have been and are possessed with a quality of the sacred in that supernatural sanctions are the means through which they are alleged to operate. The fact that ordeals are regarded as the intercession of non-ancestral spirits in matters of jurisprudence would lead to the assumption of their resiliance to change which might not be evidenced in nore vilnerable or structuraliy malleable elemerts of culture, such as material items. Things that are revered die hard; and when considered with the manifold functions of the oath-ordeal complex, what this author hopes to demonstrate is the innate religious conserve tism of the practices. 


\section{THEORY}

In anthropological research the historical approach ideally presents as the study in the field of a single culture over a long period of tine, preferably a decade or more, in order to ascertain the true characteristics of that culture as well as to postulate on the nature of Culture. This method utilizes well-known specifics such as direct observational data on ritual forms, religious beliefs and the like, obtalned through the intensive, first-hand Investigations to extrapolate to the nore general. 6 over the extended duration of this field work, one could notice changes in form and in function; and these changes would necessarily require explanation.

The approach of historical ethnography, used in this thesis, has as its puxpose a similar tenet: exploring a single culture or culture area from a more literally historical perspective through the perusal of historical (written) sources in order to assess such change as wight have occurred in the culture over an even longer period of time and from a distance betrayed by both time and space. The problems in such research are impifit--the lack of first-hand knowledge or appraisals, observational bias, differential interest on the part of the recorder, and other factors which render the work of the historical ethnographer subject to questions of interpretation. At ieast a partial purpose of this thesis has been to assess the problems of what shall be termed ethnohistoriography in relation to the definition of and interpretation of a finite aspect of a specific cultural group.

${ }^{6}$ Paus Radin, The Method and Theory of Ethnology, (New York: McGraw-Hill Company, 1933). 
The historical approach to the study of legal practices such as the sasswood ordeal and oaths among the West At lantic tribes has the purpose of observing the occurence of change through the diachronic methodology of the histoxian. The auxiliary use of the functionalist approach in che historical methodology will be secessary to explain the nature of the persistence of the practices.

\section{METHODOLOGY}

The subject of this thesis will be to explore and to define the nature of a specific cultural practice by the historical survey of that practice in a particular geographic region. For the purpose of definitional accuracy, two terms would seem to be appropriate to describe the methods employed in the thesis.

"Historical ethnography" has been described as follows.

The reconstruction of a synchronic, ethnographic description of a past stage of a culture, especially a description based on written documents contemporary with that stage. The aim (of this approach) would be to parallel as closely as possible what would be manifest in field ethnography, even though the evidence is not what the anthropologist has himself observed,

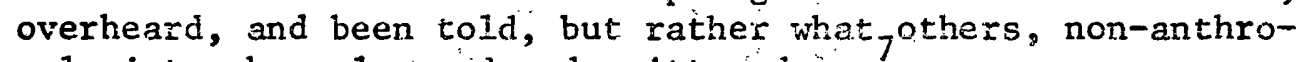
pologists, have learned and written down.

This definition should be altered to state that only one trait-complex is considered and over a long period of time, not a "temporal isolate," such that the stuuy becomes both diachronic and particularist. This may be termed limited historical ethnography. This has been achieved by piecing together often incomplete historical reports of the sasswood ordeal and concomitanc oath-swearing from different historical periods

7 Williau Sturtevanc, "Anthropology, History, and Ethnohistory," Ethnosistory, XIXI (1966), p. 454. 
so that one nay cbtain the total picture of the practice from its beginrings in the historical record to the present.

Because the initial investigations were conducted by non-anthropologists, it is the task of historical ethrographers in researching 2 single item of culture or a whole society to use the method that will be termed "ethnohistoriography "This author w111 define ethnohistoriography as the specific techriques and methods utilized by an anthropologist to research a specific topic in culture history, viewed diachronically, for the purpose of ascertaining the nature of culture change. By using such a technique the goals and methods of the historian and the ethnographer are more clearly reconciled. The diachronfc, chronological, dynamlc view of the historian concerns itself with the process in a culture and the events which manffest this process. Process involves a continuum of facts and events which each interdigitate and affect the others, and history reveals the substance of this process. 8 Ethnography, on the other hand, is concerned with the study of a culture synchronically, and characteristicaily statically, in that the ethnographers, witk few exceptions such as Paul Radin, have been unable or unwilling to invest in the intensity of research and length of field work which would make the study at one and the same time synchronic (particularistic) and diachronic (historical), The historical ethnographer, ideally working In both the field or liorary and archives, affords the approaching reconciliation of a dynamic historical methodology and the cultural speciflcity of the ethnographer. 9

8Leopold Pospisil: The Nature of Law (Eugene: Universtiy of Oregon, M.A. Thesis, 1352), F. 25 .

${ }^{9}$ Radin, op. cit. 
This thesis will not be concerned principally with the problems of ethnohistoriography; but in order to clarify the approach used in its study, some of the spaciric ethnohistorlographic problems and considerations encountered should be recorded since they in turn affect conclusions made regarding the persistence of. the sasswood ordeal among the West Atlartic tribes. The items discussed at this point are not a complete list of all problems encountered in historical ethnography, but It will be descriptive of them as they pertain to the specific topic at hand. The more specific problems would logically differ in each topic of culture history as well as the region being studied.

The most obvious source of information for the investigation of the sasswood ordeal and oath-swearing among the West Atlantic tribes is the utilization of historical, written sources. The historicel record in this region of Africa is a particularly fruitful area of study because West Africa especially has been the focus of continued contact by Indo-Europeans. since the first centurjes of the Christian era. While none of the earliest records made note, even inferentially, of the ordeals; and oaths practiced, due to the fact of these recorders' preoccupatior with aspects of trade and the writing of "travelogues," there is a substantial continuity of recorded data frow the early fifteenth century to the present, which affords roughly a six-hundred-year period over thich to investigate the ordeals and oaths and the changes, If any, that were manifested in them. In adjition, the record has been particularly varied in that the reporters of many nations and many interests have explored Sierra Leone and Liberia, thereby providing for both a breadih and eventualiy a depth of investigacion of the ways of 
Jife of the peoples living there.

There are, however, several sources of error in the utilizaticn of written sources which should be discussed in turn as they relate to the study of the oath-ordeal complex. These have been supplied principally by Mouloud Mameri ${ }^{10}$ and David Pitt. ${ }^{11}$

The first factor of ethnohistoriography which causes certain misinformation and disproportions in the historical record is defined as a "taste for the sensational and the marveilous" on the part of the early as well as more contemporary reports. The shocking has always attracted the attention of reporters; and from the earliest record of the ordeal, it has been couched in superlatives. The reason for choosing the topic of the study of ordeals and oaths rested on this facet of ethnohistoriography, for it would have proved futsle to describe and investigate the more obscure, less "impressive" cosmoilogy and ideology of the peoples of this region from the earliest times. In the earlier records and only until very recently have the reports not been concerned wth anything "subtle" or psychological. The sasswood ordeal appeared to bridge the gap between what was recorded (viz., the sensacional) and what may be regarded as religious and ideological. It was one practice which caught the eye of the chroniclers through tine, and thereby provided a sound basts fox a diachronic study.

${ }^{10}$ Mouloud Mameri. "Classification of Written Sources," Emerging Themes of African IIistory, "ed. T. O. Ranger (Nairobi: East African Publishing House, 1968), p. 84 .

II David Pitt, Using Ilistorical Sources in Anthropolcgy and Sociology (New York: Hoit, Rinehart, and Winston; 1972), pp. 46-61.

12 Marouri, iuc, cit. 
A second problem in the use of historical sources has been the recorders' attachment to certain opinions, which may be more simply termed prejudice. ${ }^{13}$ Explorers, adventuxers, merchants, government officials, and anthropologists have come to Sierra Leone and I.iberia reflecting their home nations' attitudes as well as the inteilectual dispositions of the age in which they were writing. The history of the nation concerned played a significant part in the tone of this prejudice. and these will be considered. An example of this aspect is to be seen with the majority of the British, who, from the beginning of their exposure to West Africa in the later 1500 's: (i.e., during the period of Elizabethan merchantilism) to the end of the Victoxian era, had demonstrated their apparent sense of self-important superiority and moral justification for the conquest of "inferior" nations, allegedly, in part, for the latter's own good. Such sanctimony obviously would affect the accurate recording of data since such prejudice and ethnocentrism would result in the channeling of that data into preconceived conpartments and classifications. In the case of the physical ordeals used to detect guilty behavior, such practices had been associated in the past with the witch trials in Britain during the seventeenth century; and perhaps because of the proximity of such behavior in the history of that nation, these practices were condemned as "barbaric." In addition, what were considered to be the innate biological and mental superiority of the whites, promulgated by the notions of pseudo-Darwinism extant during the nineteenth century, resulted in the dismissal of anything achieved by the blacks as being "primitive." In the case of ordeais, however, 
fact and opinion may be readily separated because of the obvious condemnatory tone used when the recoxders made judgments and also due to the fact that the formal racts of the practice are self-evident. In this case, the trouble encountered might be over-exaggeration to stress the point of "inferiority," but hyperbole has been considered and taken into account.

Related to the above, the national territorial and imperialistic. interests of the recoraing country wculd result in political motivations which in turn affected the disposition of the individual recording. Again with regard to Britain iis the later eighteenth and nineteenth centuries, national interest was directed to conquest in the development of the Empire. The scouts for the Empire, with the explorers such as Sir Richard Burton and John Hawkins, demonstrated in their recoris the notion politically popular at the time that it was white man's duty, if not burden, to control Africans, attempting to substantiate and to prove In their journals the duty of the white to supervise the black. Individuals in the service of the country, such as government officials, would more likely reflect those national political interests than the independent explorers, because of their vested interest in political and societal manipijiation rather than mere observation. The former had a purpose, an "axe to grind," in their recording of events in reference to the goverment's position while the lattex had only a disposition and prejudice.

Despite these greater national attitudes and political motivations, the most significant source of error in these records would appear to 
lie with the individual, This factor has been called observational bias, 14 which is more variabie than the previous three scurces of error because an individual's predilectiuns are less predictabie. Different individuals would have different abilities and different interests. As will. be demonstrated later in describing some of the various records, missionaries differed from the explorers in their nanner of recording the ordeal, usually in tone rather than in substance of the description. Such factors as the health and education of the recorder were also taken into consideration in determining the objectivity or subjectivity of the recorder, whetiner he might be peevish, complacent, or "over-emotional, "15 that is, how his objectivity as a recorder might be affected. Confidence in the word of the individual transmitting the account must be developed and assessed; the records of the individuals describing the ordeal are not the same and whether these differences are significant should be assessed with each case in texms of observational bias. As mentioned above, these discrepancies are seen as minor in that hyperbole and "descriptive indiscretions" are easily distinguished from what may be regarded as fact.

There is another source of error present in the study of written sources which may be considered as appiicable to the nistorical investigation of the sasswocd ordeal. In relation to the individuals' ethnocentric notions, few of the recorders, except for Adam Afzelius, ${ }^{16}$ were

${ }^{14}$ Pitt, 1cc. cit. 15 Mamauri, 1oc. cit. 16 Adam Afzelius, Sierra Jeone Journal 1795-1796 (Uppsala, Sweden: Studia Ethnograpnica Uppsaliensa, XXVII, i95i). 
aware of the ideas of causation of the inhabltants of Sierra Leone and Liberta with regard to legal practices. ${ }^{17}$ Thers was apparently awaxeness of the link between the ordeals and supernatural determinations of guilt, but the underlying ideologies other than the legal functions were not considered by the majority of the recorders. Basically, though, they vere Ignorant of the relations between cause and effect in the law. The Victorian recorders were not concerned with the functions of these practices but rather with describing the "bare facts." Interpretation has been designated as the task of later investigators; and in this sense, it: may be assumed that such a deficit has been beneficial in that the mere recording of events would be more comparable to direct fleld observation than the ethnocentric, and false, interpretations of events by the earlier records which might well confuse later researchers.

Before concluding the discussion of the problems encountered in researching historical sources, it would be appropriate to consider one of the other techniques used by the ethnohistorian and judge the range of its use in the study of legal-religious practices.

Oral tradition involves the folk or "emic"18 view of history, and in this respect the folk tales and myths of Sierra Leone and Liberia could be regarded as a likely area for investigation. In describing the assumptions of studying oral traditions, Ruth Finnegan has reported that "oral tradition is something uniform, something that can it

17 Mamouri, 10c. eit.

18 Marvin Harris, The Rise of Anthropological Theory (New York: Crowel1 Press, 1968), p. 571. 
treated as an undifferentiated and self-evident entity (such that it) leads to a tendency to speak of oral tradition as a source in itself without the need to describe and analyze the scurce." 19 Such a study would appeax particularly germane in researching a subject arca of law and religion, which, in keeping with the definition of origin myths provided below (p. 48), would indicate that these essential areas of a society's culture would need to be "codified" in their oral traditions. Unfortunately, the only such record which has come to this writer's attention is the Dan myth on page 50, which describes the origias and functions of the sasswood ordeal. Proverbs form another aspect of oral tradition which might be utilized in this case, being repeated during ordeals and oaths to exemplify specific points ox law.

Having provided an introduction to the general ethnohistoriographic problems encountered in researching the sasswood ordeal and oath-swearing among the West Atlantic tribes, the more specific attitudes reflected by the recording countries will be described in the fourth chapter.

\section{WEST ATLANTIC TRIBES}

The West AtIantic txibes of Sierra Leone and Liberia were seiected for their location on the coastal regions of West Africa. These regions have a particularly rich history of exploration, from the first Portuguese to the most recent anthropologist. An active slave trade and colonial feriod, dotted with the records of zealous missionaries, provide an exceilent recorded series of observations from the fifteenth century

\footnotetext{
${ }^{19}$ Ruth Finnegan, "Oral Tradition," History and Theory. IX (1970), p. 195 .
} 
to the presert as well as a relative abundance of data from which to draw.

The designation West Atiantic ("1e cercle occidental de l'Atlantique") has been proposed by Baumann and Westermann. 20 The unity presented by this group is not racial or linguistic, for these differences are great, the latter falling into three broad classifications (Kru, Atlantic, and Mande). 21 The principal deternining factor has been cited as the lack of a highly centrallzed form of government in the formation of local petty chiefdoms. It has been marked as the area where typlcal West African "civilization" encounters "la paléonigritique," and the amalgamation of the tro lends this region its distinctive characteristics. In the words of Baumann and Westermann,

From the Irory Coast to Senegal, one finds particular traits that are alike among the Kru, the Mende, and other West African peoples. These traits are especially indicated in their political organization, which from the beginning has been strongly gerontocratic and democratic; in their economic mode (agricultural with rice as the principal crop); in the form of their 22 secret societies; and in their myths and religious structures. 22

The main tribes included in this region and in this thesis are the Wolof; the Bakwe, Bassa, Sikon, Kwa, Grebo, Kru, and Sapo of the Kru tribes; the Bulom, Kissi, Limba, Sherbro, and Temne of the Atlantic tribes; and the Dan, Gio, Gagu, Kono, Kpelle, I,oko, and Mende of the Mande groups. 23

$20 \mathrm{H}$. Baumann and D. Westermann, Les Peuples et Les Civilizations de L'Afrique suivi de Les Langues et Lrducation (Paris: Payot, 1967), p. 307.

${ }^{21}$ George Murdock, Africa: Its People and Their Culture History (New York: McGraw-Hil1, 1959), p. 260.

22 Baumanr and westermann, op. cit., p. 368.

23 Murdock, op. cit.; F. 261. 
V. PROSPECIUS

A prospectus of the contents of the chapters following shall be given at this time to afford the reader some idea of what to expect in each section and some notion of the development of the subject matter.

Chapter II will be concerned with the definition of the generic relation between law and religion, as these areas are involved with similar and overlapping mechanisms of social control in Africa. The region of mutuality of $12 w$ and religion will be seen to lie in ritual. A special type of technological ritual--divination--will be presented as a mechanisn whereby difficult matters are decided with the help of the supernatural; and oaths and ordeals present as a distinct aspect of divination utilized to try legal matters, especially those concerning social high crimes of adultery, murder, witchcraft, and theft.

Chapter III will deal with the specific sasswood ordeal of poison and the concomitant oath-swearing as compiled from the numerous historical sources which have made reference to it. The distribution of the poison ordeals in general will be presented as well as the spatial iimitations of the sasswood ordeal. Descriptions will be made of the various characteristics of the trait-complex, the poison's action, the ritual and ceremonial aspects, the specialist involved, and the cases in which the ordeal is used. Intracultural correlations will then be presented to demonstrate the interdigitation of the elements in a culture in relation to oaths and ordeals. Finally, some functions, other than the obvious guilt-detcrmining aspect, wili be presented to demonstrate the various ways in wich the complex has been used. The emphasis in this section will be described as a composite of elements which had been 
differentially described in the historical record.

Chapter IV will present a general discussion on the probability of the sassrood ordeal's propensity for change and persistence; that is, which elements in it are likely or unlikely to change. A discussion of such changes as are manifest and probable et"ology for the changes will be presented. The various historical influences will be presented and will include Jslam, slavery, colonialism, missionary proselytisation, and the effect of the modern wor $1 \mathrm{~d}$ on the practices.

In Chapter $V$ the conciusions regarding the conservative nature of the ordeal as an aspect of law and religion will be shown, in addition to some further problems of ethnohistoriography. 


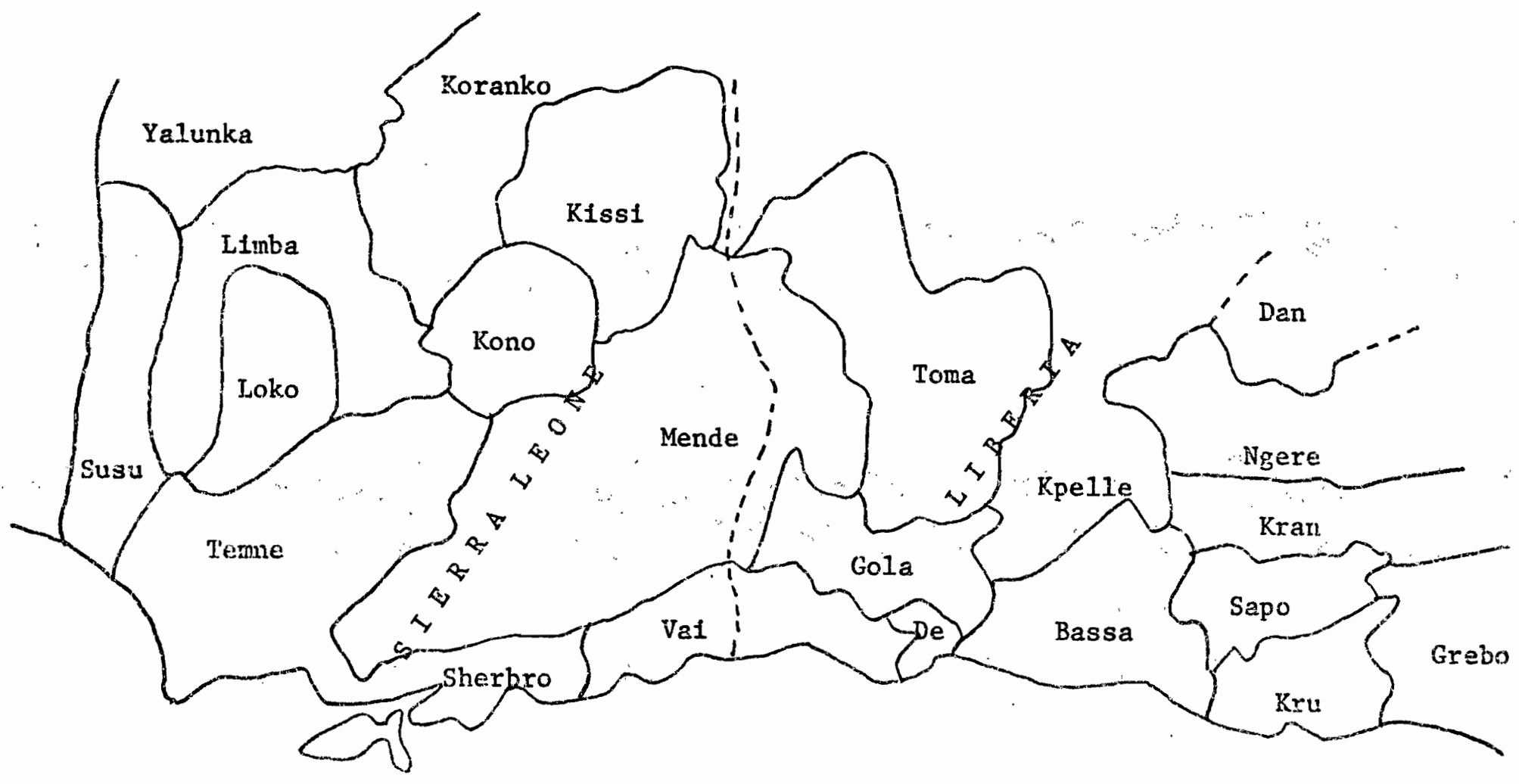

Figure 1. The West Atlantic Tribes

of Sierra Leone and Liberia 
CHAPTER II

THE RELATION OF LAW AND RELIGION 


\section{CHAPTER II}

\section{THE RELATION OF LAW AND RELIGTON}

Before defining the nature of the specific sasswood ordeal and oath-swearing complex, it would be well to discuss the relationship between law and religion. The influence of each on the functioning of society will be presented as well as their area of overlap, especialiy in the aspect of ritual. Such a discussion is intended to afford the reader with an initial orientation to the concepts of 1 aw and religion.

\section{SOCIAL SANCTIONS}

Rules for social control are necessary to keep in check the various tensions, stresses, and conflicts which one meets in deailng with other members of the society. These have been called social sanctions and are defined as follows.

A sanction is a reaction on the part of a society or of a considerable number of its members to a mode of behaviour which is thereby approved (positive sanctions) or disapproved (negative sanctions). Sanctions may be further distinguished accoriing to whether they are diffuse or organized; the forner are spontaneous expressions of approval cr disapproval by the members of a community, while the latter are sociai actions carriad out according to some traditional and recognized procedure. 24

Because these tensions require the operation of sanctions and are weak

24. R. Radeliffe-Brown, Structure and Function in Primitive Society (New York: Free Press, 1965), p. 205. 
points in the society, in that one is more likely to transgress the noral code in these areas, and because these aspects of vulnerability are important and essential by definition of the individual society, formalized means of handling the breachs of the established moral code are developed. 25 By formalized, one should interpret this to mean that the laws and moral rules are codified in the mythology and oral traditions, reflecting as they do, in sacred guise, the moral tenets of the society. Examples of this would be the Bible, the Koran, and the Edda of Scandinavia as well as folk tales of other nations.

The mecinanisms of social sanctions are various, but the principal characteristic of all means of social control is that they raflect the ideal (that is, the "mental template") of the society with respect to what is considered important enough to set aside for special 1egal and religious observance. ${ }^{26}$ For instance, sanctions and rules function to restrict certain types of behavior, such as incest and eating habits, the violation of which is alleged to upset the "cosmic balarce" and to offend the supernatural. $^{27}$. In addition, other societies have established formal courts of law. In most cases, public opinion operates to keep in check moral transgressors by condemnation of the deviant actions, ostracism of the errant actors, and punishment when necessary. In the words of Felix Keesing in describing Bronislaw Malinowski's "charter" of the society, :it involves rules, backed by sanctions of social, and

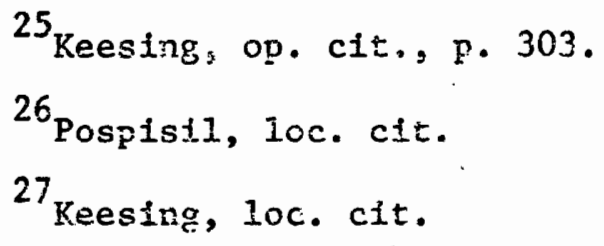


perhaps of supernatural, opinion and action. ${ }^{28}$ Whether there exists Informal control, or diffuse sanctions (such as among the Bushmen whose "police force" is ridicule and ostracism), or institutionalized control and codification of laws (as among contemporary urbanizad societies), the underlying principle of the law is that it is a systen of regulations regarding the weak points in the society's moral and ethical code. ${ }^{29}$ Indeed, if there were not these aspects which might potentially be violated, there would be no need for laws and rules regarding their braach. A11 such social sanctions operate on the basic assumption of the "desire of the individuai to obtain the approprobation and to avoid the disapprobation of his fellows." 30

In the ethicoreligious systen of many societies, moral law and natural law are indistinguishable, in that supernatural sanctions, as reflected in the group's mythology and oral traditions ("charter"), are thought to order men's lives and keep them in check. ${ }^{31}$ Because each antiand asocial action among the members of a small soclety has such potential1y far-reaching effects in terms of social cohestion and function, measures to avold or to minimize these tensions are sought not through an unemotional set of rigid laws and ethics, but rather by means of an emotionallyinfused set of religious and supernatural models, sanctions, and myths,

\section{Ibid.}

${ }^{29}$ E. A. Heebe1, The Law of Frimitive Man (Cembridge: Harvard University Press, 1967).

${ }^{30}$ Radcliffe-Brown, op. cit., p. 206.

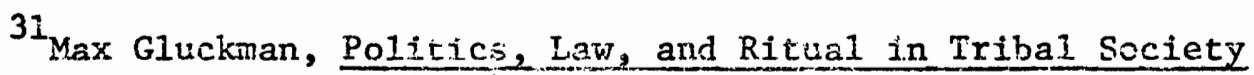

(New York: Mentor Books, 1365), p. 277. 
Where the smallest hunting and gathering grovp, such as the Bushmen, may function soleiy on the operation of public opinion, others of greater cultural complexity or larger size, such as the West Atlantic tribes, may require nore complicated means of control due to the greater number of members. Legal-religious jurisdiction appears to be the most efficacious means in this respect in that supernatural sanctions are pervasive, strict, and divinely ordained.

\section{RITUAL}

Religion, like law, has a similar purpose of moraliy guiding the members of the society. "Religion is a set of rituals, rationalized by myths, which mobilizes supernatural powers for the purpose of achieving or preventing transformations of state in man and nature." 32 The important aspect of religion described above is the attainment of social equilibrium, or the ritual means by which homeostasis is achieved during moral and social crises. Ritual is a chief mechanism demonstrating the assimilation or amalgamation of law and religion in this aspect. Ritual is a prescribed set of specific procedures which must be routinely performed for the goals of assuring the assistance of the supernatural in allowing the continued smoith functioning of the society. Ritual also appears dramatic and possessed of sacred words and actions. 33 Furthermore, ritual is seen to be expressive in that differences in social sta-

32 Anthony F. C. Wallace, Religion: An Anthropological View (New York: Randoir House, 1966), p. 107 .

${ }^{33}$ John Messenger, "The Roie of Proverbs in a Nigerian Judiciai Systen," Southwestazn Journal of Anthropology, XV (1959), p. 64. 
tus, lineage roles, and other cultural functions which are not clearly delineated in the society in more mundane terms are repeatedly, emotionally, and systenatically reaffirmed to the members of the society. 34 This aspect is important in preserving social cohesion in that the locai hierarchy and positions of one individual relative to another are confirmed in the presence of "divine witness."

With regard to legal questions and the ireach of moral codes, the ritual is a means by which apologies and explanations are provided to the supernatural such that the "holy vengeance" will not be wreaked. In the words of Max Gluckman, "ritual emerges as a result of the 'moral discomfort' of the group when confronted with a breach of natural order ... There is nothing for it to do but to iay stress on values to which all men (must) subscribe, regardless of their particular loyalties and interests." 35

\section{DIVINATION}

Divination, of which oaths and ordeals belong to a special classification, is a special form of ritual, subscribing to a schema of natural events; and it is therefore termed technologicai ritual. ${ }^{36}$ Divination is a ritual which aims to extract information from nature; and it is performed at times when a decision must be made (as in the aforementioned breachs of the moral code), and the actors have either insufficient

34 William Lessa and Evon Vogt, A Reader in Comparative Religion (New York: Harper anj Row, 1965), p. 299.

${ }^{35}$ Gluckman, op. cit., p. 255.

36 Wallace, op. cit., F. 108. 
knowledge about the crime or are urwilling to accept the responsibility for making a decision on their own. ${ }^{37}$ In this sense, religious divination is always pragmatic in its congruence with the system of mythological beliefs; and it appears that "judgment, directly, if apparently arbitrar1ly, from supernatural author1ty" determines the deciston. 38

The relaticn of 1 aw and ritual is clear in this respect.

The supernatural aiso enters into the law-ways of substantive rules, but as an instrument of judgment and execution of justice when men's infallible means of the determination of evidence are unequal to the task of establishing facts ... the spirits know the truth. They are omniscient $\ldots$ and if properly appealed to, they will judge the case. 3

A special aspect of divination in the consideration of legal questions is its technique of supplication to the supernatuxal to provide viable answers to those questions, such that the society can resolve its particular difficulties with the least amount of tension resulting from indecision.

Divinatory rituals have the following goals which may be summarized: reducing the duration of individual indecision in the face of possible dysfunction by not being able to make the decision; accomplishing a more even consensus within the group, with a minimum of offense to its members; and inspiring the persons who must execute the decision with sufficient confidence, unimpeded by anxiety, ard to provide a randomization in decisson-making. 40

\section{Ibid.}

${ }^{38}$ Ibid.

${ }^{39}$ Wallace, op, cit., p. 110.

${ }^{40}$ A. H. M. Kirk-Greene, "On Swearing," Africa, XXV (1955), p. 43 
IV. " OATHS AND OROEALS

The oath-ordeal complex has only been discussed to a limited extent in the anthropological literature, and a definition of the complex will be necessarily a ccinposite of ordeals and oaths as described histo-rically for the tribes of Sierra Leone and Iiberia.

\section{Oaths}

An oath may be defined as an "invocation to a supernatural being or agency, and punishment for an infringement of an oath falls altomatically." 41 The oath's action operates through the means of a material object, such as a bit of leather or a sacred object. 42 The purpose of the oath lies in ritually pleading one's innocence with vords by a type of imitative magic ${ }^{43}$ : a direct symbolism is involved in the formation of the oath, such as "If I murdered the 01d Washer Woman, may my life be taken as this chicken's is." 44 The effectiveness of this method has been described. "Since in primitive society the spoken word is thought to exercise supernatural power in its utterance and repetition, It gives efficacy to the actions performed and the episodes recounted as an uttered rite." 45 In this sense, words themseives are thought to be

${ }^{41}$ Ibid.

42 Ruth Finnegan, Report on the Limba of Northern Sierra Leone (London: International African Institute, 1964), p. 120.

${ }^{43}$ Sir James Fraser, The New Golden Bough (New York: Mentor Books, 1959), P. 35 .

${ }^{44}$ Kixk-Greene, op. sit., p. 40 .

${ }^{45}$ Edward Fashole-Luke, "The Theme of Myths," Sierra Leone Bulletin of Religion, VII (1965), p. 35 . 
the direct causal agents. ${ }^{46}$ The thieat of supernatural retaiiation for social transgressions and crimes and the negic of words embodied in affirming the oath appear to be powerful enough in themselves to achieve and maintain a legal, poilcing function as a mecianism of social control. Their effect is almost ent:rely psychological; its means is fear of supernatural "sleuthing" and retaliation.

An important factor relating to the definitions of oaths and ordeals was provided by Ruth Finnegan. 47 She drew the distinction between oaths and ordeals in that in the case of oath-swearing there appears to be a "general warrant" out for the unknown guilty party. The tone of the oath is to suppiicate the spirits to reveal the guilty one and to punish him. It might be interpreted that in the cases of oath-swearing, the social anger is either diffuse (that is, it does not require a specific focus), or else that it also is so slight that a generalized "let them take care of it" seems to suffice to pacify the populace. Ordeals, on the other hand, are directed against a specific party, which by contrast might be interpreted to mean that the social tensions require what may be called a "scapegoat" for community satisfaction.

Another interesting facet was pointed out by Finnegan in her discussion of swearing (oaths) among the Limia. In it, she stated that blacksmiths are always associated with the swearing ceremony as well as with ordeals. As Finnegan states, "the smith is the most powerful and universal of the experts in varlous rituals. He t: always purifying

\footnotetext{
46 John Beattie, "Ritual and Social Cinange," Man, I (1966), p. 59. 47 isnegan, op. nit., p. 24.
} 
people, making and 'pulling' swears, and conducting sacrifices at the chief's hut. People even say occasionally that he is more fmportant than the chief." 48 In many parts of Africa the smith appears as the feared and respected class of specialist, closely. assoclated with the rellgious realm as manifested by the taboos surrounding him. One author has prom vided a reason for the awe in which the smith is held. Fire is the element of the smith's craft through which he works; and fire has been revered as a power divinely given to man. Since the smith uses it, this gives the appearance of his interference in the processes of the cosmic forces. This was further viewed as "the manifestation of a magico-religious power which could modify the world, and which, consequently, did not belong to this world." $49^{\circ}$. In addition, another author has noted that there is a direct relationship implied between the smith and the "nether. regions." 50 Such an association with the dark aspects of the supernatural, such as witches, would make the smith a likely candidate for seekIng out the guilty by the rnsterious means manifested in swears.

Swearing and oath-taking may be summarized as being a means by which supernatural sanctions are generally invoked, usuaily through some sacred object, such as a special cool or a grigri bag, or through the name of a spirit. Their efficacy is thought emically to operate through the psyciolocial means, in which the guilet of the individual, as opposed to his shame, manifests itself by the internal sanctions: the

${ }^{48}$ Finnegan, op, cit., p. 121 .

49 Mircea Eliade, The Forge and the Crucible (London: Rider and Company, 1962), p. 79 .

50 J.-D. CIëbert, The Gyosies (Nev York: Penguin Books, 1967), p. 36. 
secret avowal that "I have done wrong" and the conviction that one will be "caught" if guilty. Swears operate from the Inside-out, in other words.

\section{Ordeals}

An ordeal, on the other hand, operates by a combined psycholofical and physlological mechanism. An ordeal has been described as a "method of invoking the aid of supernatural povers to settle disputes or to test the truth of an accusation. It usually consists of severe and dangerous tests." 51 The psychological basis for the effectiveness of the ordeal is to be seen again in the fear of consequences of the pain and of the crdeal. Itself and in the fear of the sanctions against the Individual, both from the supematural and from his fellow members in the society, should he be proved guilty in the matter at hand. In addition, the psychological operation resides in the individual's conviction that if he is innocent, nothing will happen to him, such as in the case of oaths. Note has been made that the accused's fear of corsequences resulting from culpability may exacerbate the ordeal's efficacy in determining the truth, much as the lie-detector is said to operate. 52

The physiological basis of the ordeal should appear readily apparent in its operation through pain and other physical effects to either force confession or otherwise resolve the issue through the arbitrary physical responses of the accused. The first classification of ordeal

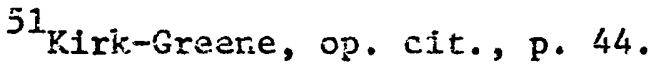

52. M. Roberts, "Oaths, Autonomic Ordeals, and Power," American Anthropologist, iXVII (1965), p. 186. 
is one in which the response of the accused may be directly controljed by the individual undergoing the ordeal, such as the use of physical skills employed in feats of strength and the like. In addition, the second is the type of ordeal which has been termed "autonomic," which is "that subtype in which the judgment of success or failure, guilt or innocence, is dependent upon involuncary (physiological) responses such as blistering." 53 Also included in this category are bleeding, burning. floating, and vomtting. This sort of ordeal is significant in that more than the other type, its action is independent of direct human control and manipulation in that there are differing individual responses to the various tests. This gives the appearance of supernatural intervention. This impression is intensified by the seeming caprice of the ordesi's operation. Where in point of fact the dose and quality of the poison are controlled to some extent by the sasswood specialist, the exact effect that the poison will take is capricious. Such a method of divination permits those who are indecisive or those who are not in a position to make a decision for wich they wish to be held responsible to make a decision without assuming direct responsibility. After all, it was the supernatural who decided the issue.

Other than the supernaturaily legal aspact of oaths and ordeals, these forms of divination aliow men to "control" their lives and to attempt to knol the unknown to at least a certain degree. One thing that can be said for all men is that each individual has some measure of uncartainty about the unknown elements of everyday life occurences ${ }^{53}$ Ibid. 
and particulariy uninowable events such as witchcraft and frequentiy murder. With regard to the specific problems of determining guilt or Innocence in legal cases, oaths and ordeals, in the particular sphere of maintaining the noral code, allow an individual who is immobilized by a difficult decision to make an effective and resolute choice without "devisive indecision." In this sense, oathis and ordeals would function to lessen the uncertainties of this one aspect of their lives.

These forms of divination also are thought to have a randomizing effect in that by providing the element of chance in a given event, it randomly directs the activities to the resolution of a problem and thereby avoids "deletericus regularity." 54 This indicates the purposeful avoliance of a ragularized patten of behavicr by means of the "chance1ike" divination. However, ordeals are seldom precisely random due to the intervention of human agents with knowledge of their special moral code as well as public opinion which varies from case to case. One may conclude that divination causes a mild period of constructive social uncertainty and flux which necessitates the re-affirmation, through ritual means, of social and cultural values and standaras which had been threatened temporaxily by a transgression on the part of a particular "criminal" individual es vell as attaining a consensus regarding the particular issue. 55 Divination--oaths and ordeals--thus effectively

54 Omar K. Nioore, "Divination: A New Perspective," Reader in Comparative Religisn, Bd. W. Lessa and E. Vogt (New Ycrk: Harper and Bow, $1965)$, p. 377 .

${ }^{55} \mathrm{G}, \mathrm{K}$. park, "DLvination ana Its Socjal Contexts," Reader in Comparative Religion, id. W. Lessa and E. Vogt, (New York: Harper and Row, 1965), p. 380 . 
channel public opinion and belief through solemn and dramatic, supernaturally sanctioned means, namely ritual.

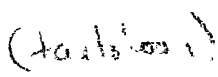

Two theories have been postulated regarding the nature and function of oaths and ordeals in a society. First, it has been thought that oaths and ordeals occur in trials, where physical force and strategy are used, but where such flexing of power muscles is insufficient to permit the resolution of an indeterminant situation without incurring the risk of excessive losses in terms of life and 11mb. 56 The threat of probable supernatural punishment in this case would appear to be greater than any harm that a mortal might inflict on anothe: : and the effectiveness in such a situation would rest with the anxiety achieved by the fear of "cosmic repercussions." This would relate to the maintenance of cohes1on.

The second hypothesis is that "oaths and ordeals are psycholog:cally viable cultural patterns which probably contributed to more correct and/or successful outcomes than otherwise, in terms of the legal system, but not necessarily in terms of the viewpoints of the individuals." 57 Related to the first hypothesis, this theory promotes the Idea that high levels of anxiety resulting from fears of supernatural retribution resuit in physiological (psychoscratic) responses in keeping with the actual guilt (or innocence) or the accused. One would wonder what would be the fate of the personally nervous or the neurotic individual in such a case.

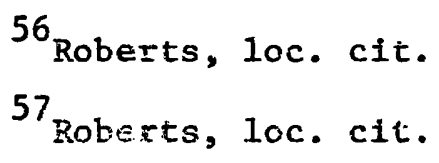


In sumary, caths and ordeals belong to the classification of technological ritual in which legal situations which cannot be resolved by human judges, either tinrough their igrorance of the truth or through the fact that they do not wish responsibility to rest in other hands. Oaths operate by means of a "general warrant" in that a specific individual is not accused, but the spirtt of the materiai, sacred object through the "swear" works will seek out the guilty; and by his sickness, accident, or death, his culpability will become apparent. Ordeals deal directly with a specific individual who has been blamed for a specific crime, and usualiy has professed his innocence, such that a "test of faith" is required. Oraeals are characterised by a seif-contained mechanism of punishment-to-fit-the-crime, acting at one time as judge and executioner. 
CHAPTER III

THE SASSWOOD ORDEAL OF POISON 


\section{CHAPTER III}

\section{THE SASSHOOD ORDEAL OF POISON}

Polson ordeals are distribuced throughout Africa and are limited to that concinent. They appear to be African inventions and to have diffused throughout that continent by means of simple contact diffusion. 58 Furthermore, there is a qualitative difference between the type of poison ordeals practiced in West Africa and those from other sections of Africa. In East and South Africa, as well as in some parts of West Africa, namely the coastal regions of Ghana and Nigerta, 59 the poison ordeal is administered to chickens and other small domestic stock, whose death or survival, in addition to the pattern of their responses, are divined by a speclalist who theraby determines the answer to a particular question. 60 In West Africa, particularly in Sierra Leone and Liberia and the Ivory Coast, in addition to the inland regione of Ghara and Nigeria, the poison ordeal deals directly with human beings; and the justice administered is, in this sanse, instantaneous and direct. The present study, therefore, limits itself to the latter type of poison ordeal with human recipients of the poison.

58 Roberts, op. cit., p. 205.

${ }^{59}$ In Ghana and Nigeria, the shift to chicken ordeals in lieu of human ordeals is probably the result of more intense westernization in these regions.

50 E. E. Evans-Pritchard, "Consulting the Foison Oracle among the Azande," Keader in Compazative Religion, Ed. W. Lessa and E. Vogt, (New York: Harper and Row, 1965), p. 34i. 
The polson ordeal goes by many names amorg the variouis tribes practicing it; but in most cases, the phrase nay be translated as "drinking fetish," in which case "fetish" should be interpreted to mean the charm or special wateriai item endowed with powers and the protection of the supernaturai. 61 Poison is an example of sich a "sacred" material item which can be taken into the body. In the words of another source, "... the strongest of all ordeals is that in which the sacred object is eaten or drunk." 62 This would indicate the gravity of matters being considered if the sacred object must itself be ingested and the individual suffused with the power which will seek and find the truth within him. The phrase "drinking fetish" would seem to indicate this idea. Among the groups of Sierra Leone and Liberia considered in this thesis, the sasswood ordeal forms a major sort of poison ordeal. The word "sasswood" Is apparently derived from the local mispronunciation of the Anglo-French word "sauce" used by seventeenth and eighteenth century saflors to describe something pungeant or spicy in taste or behavior. ${ }^{63}$ This would indicate an extra-African term applied to an indigenous practice. Kru, for example, provides two contemporary meanings to "sauce" or "sass": a violent purgative measure (the polson's usual action) and a cheeiny, riotous benavior ("sassy"). 64

${ }^{61}$ Geoffrey Parrinder, West African Religion (London: Epworth Press, 1949), p. 205 .

${ }^{62}$ Kirk-Greene, op. cit., p. 51. p. 1065 .

${ }^{63}$ Sir Hariy Johnston, Liberia (London: Dodd, Mead, and Co., 1906), ${ }^{64}$ Ibid. 
Terms other than sasswood exist for the poison ordeal, wach as the "redwater crdeal," which at one tine was alIeged to be attributed to the draught's red hue, but which view hap been contested. 65 other groups such as the Mano, Dan, Vai, Sapo have called the sasswood ordeal gl1 and aiternativaly gri znong the Gio, 56 which may be cormed from grigri, which is the term for charas designed to ward off evil and to bring good luck. In fact, Eri. mu is the term used anong the Mano and the Gio. 67 Anong the Sherioro, the ordeal is called kong, ${ }^{6 E}$ while among the Vai it has been termed kony. ${ }^{9}$ Among the Kru, Dan, Grebo, and lalfGreto, the crdeal is called ge du. $70,71,72$ Among the Kpelle, this is called kafu. ${ }^{73}$ Among the Grebo, it is also named meli as an alternative, while anong the Susu this term is also used, 74 The Teme refer to the sasswood ordeal as anglrong. 75 In the whole area of the west

${ }^{65}$ Afzelius, op. cit., p. 26.

${ }^{66}$ G. Schwab, Tribes of the Liberian Hinterland (Cambridge: Harvard University Press, 1947), p. 447.

67 Ibid.

68 ${ }_{\mathrm{H}}$. Ha11, Sherbro of Sierra Leone (Philadelphia: Pennsylvania, 193a). ${ }^{63} \mathrm{~J}$. Blltikofer, Reisebilder (Leiden: Bri11 Verlag, 1890). 70 Johnston, op. cit.: p. 1067.

71E. Fischer, "Erzuhlgut der westlichen Dan iri Liberia," Anthropos, $\operatorname{LXII}(196 \%), \operatorname{sp} .685-744$.

${ }^{72}$ Schwab, 10c. cit.

${ }^{73} \mathrm{~J}$. Gibos, "The Kpelle of Liberia," The Peoples of Africa, Ed. Janies Gibbs (New York: Holt, Rinehart, and winston, 1965).

74 Josegh Corry, Observations (London: Cass Publishers, 1968).

${ }^{75}$ V. Dorjahn, "Some Aspects of. Tenne Divination," Sierra Leone Bulletin of Religior, IV (1962), pp. 1-9. 
Atlantic cluster, however, the term "sassvood" has come to indicate more than just one type of oxdeal and may be faisen to mean, depending on the context, any form of ordeal used in the detection of guilt or innocence In tratters of great importance to the groups of this region. 76

\section{THE OPERATIOH OF THE ORDEAL}

Upen the death of an individual among the Nest Atlantic tribes, a "palaver," or group discussion, led by the elders of the village, ensues and concerns itself with ascertaining who shall be accused of witchcraft, especially in cases of unexpected deaths and accidents, with the exception of the rost obvious of natural causes. The decision having been made, upon recominendations of the $\underline{z o}^{77}$ or by the family of the deceased or by public consensus, the accused is openly faced with the charges and is held to account for then. Before the assembled villagers, the accused must either confess his guilt or protest his innocence; and if the latter course is chosen, he inust submit to the sasswood ordeal. Most do so willingly because, believing in the reality of the prcofs of the ordeal, they do not fear the trial if they are innocent and fear its consequences too much if guilty and therefore confess. After the ordeai has been dectded upon as the means for determining culpability, a further palaver is conducted to ascertain when the ordeal should take place. The waiting period before the trial may last as lorg as six months or as briefly as instantaneously. 78 The confinement of the accused before

76 Jaries Cibbs, "Poro Talues and Courtoon Procedures in a Kpelle Courtroom," Southwestern Journal of Anthropology, XVIII (1962), pp. 341-50.

${ }^{77}$ see page 43.

78 Afzelius, op. cit., p. 91. 
the trial is with the fanily or friends of the accused and often in another village, for his protection. Before the actuai ordeal begins, a brief pre-trial administration of poison occurs, presumaty to determine guilt or innocence before the actual trial, at which time the poison w111 be more stringent in j.ts actions. 79

A brief description of the basic oath-ordeal complex derived from the historical. souxces nay be eited from the exampie given belon for the Mende of Sierra Leone. Other variations iri this basic form of the ordeal will be noted later as they occur. A nore extensive description of the ordeal may be obtained by reading Afzelius. 80

A good deal of ceremony is used in connection with the administration of the ordeal. At a secret and sacred place In the woods, the people who assembled to see it adninistered form themselves into a circle, and the pots containing the liquid are placed in the center of the enclosed place. The accused then comes forward, having the scantiest appare1, but with a cord of palin-leaves bound round his waist, and seats himself in the center of the circle. After $\mathrm{r}_{i}$ is accusation is announced, he makes a form acknowiedgement of all evil. deeds of his past life, then invokes the name of God three times, and imprecates his wrath in case he is guilty of the particular crime laid to his charge ... He then steps forward and drinks freely of the red water.

If it nauseates and causes him to vomit freely, he suffers no serfous injury and is at once proved innocent. If, on the other hand, it causes vertigo and he loses his self-control, it is regarded as evidance of guilt, and tien all sorts of indignities and cruelties are practicer upon him. A general hovil of Indignation rises from the surrounding spectatoxs. The children and others are encouraged to hoot at him, pelt him with stones, spit upon hin, and in niany instances he is selzed by the heels and dragged through the bishes and over

79 Ibid.

${ }^{80}$ See Appendix B 
rocky places until his body is shamefully lacerated and 11 fe becomes extinct. On the otiner hand, if he escapes vithout injury, his character is plifified,... After all this is over, he assembles the principa? men of the town and arraigns his accusers before them, who in their turn, must submit to the same ordeal. No particular quantity of the red water is prescribed, and the amount ministered alvays depends on the scale of feeling in the comnurity against the accused. 81

It will be noted that guilt is determined by a combination of the result of various administrations of the poison. These have been called "cumulative trials," in that the guilty one is subjected to even nore triais hy sasswood until the members of the society attending the ceremony are satisfied with the results, either the accused's guilt or innocence. 82

Among the salient points of importance to be noted from the above description of the sasswood ordeal is the public nature of the trial so that consensus nay be regarded as necessary for the effective completion of the trial. Though earifer chroniciers such as Afzelius had reported that a pre-trial "ordealette" took place for the preliminary determinatior of culpability, ${ }^{83}$ most cf the whole procedure from accusation to resolution of the verdict may be considered to be public. Afzelius has made note of the fact that the audience participated actively in all stages of the procedings, from the supervistion ci the infusion of the bark to chasing the accused after the trial was over to assure horesty. 84

${ }^{81}$ Reverend $j$. Leighton Wilson, western Africa: Its Histomy, Condition and Prospect (New York: Harper Brotiezs, 1856).

82 Robertś, 100 . cit.

${ }^{83}$ Afzelius, op. cit., p. 25.

${ }^{84}$ Ibid. 
Another characterisclc is the highly ritualized nature of the ordeal: the circular formation, the "yalaver" of the elders, the invocation oi the supernatural, and the exectition of justice are performed with supernatural sanctions. The definiticn of and explanation of the use of ritual as it pertains to the sasswood ordeal has been described ear1ier.

A further aspect of the ordeal was described by Haxriet Brittan, writing in 1860, She remarked that substitutes for the accused (i.e,, by proxy) were not allowed and that all such substitutes could prove was their Innocence or guilt of witchcraft ur adultery and not the accused's. 85 This was the only source which made reference to such a fact.

\section{THE POISON}

The poison used in the sasswood ordeal is derived from the bark of the tree Erythrophloeum guieense. Other sources have reported the polsonous bark to be derived from various species of the genus Erythronhloeum, such as E. ivorensis. ${ }^{86}$ The bark is first pounded in a mortar, which is reserved for this purpose, and then scaked in cold water until the alkaloid poison has been laached fron the fibers. When this stage has beer echiered, the infusion is said to be a reddish hue and bitter in taste; and some have described it as being a nember of the curare group shose action is to relax muscles, raise the biood pressure

\section{Harriat Brittan, Everyday I.ife in Africa (London: Fudney and} Russells, 1860), p. 80 .

$$
{ }^{86} \text { Afzelius, op. cit., p. } 26 .
$$


and to reduce pulse and respiration. ${ }^{87}$ Most sources agree on the chemical's action as a vile and volere irritant and powerfud emetic. Both of these functions would be manifested in the vomiting, which results determine the innocence of the individual accused of crimes. Those who do not regurgitate are juciged guilty.

It should be noted that the action of the poison is roughiy unpredictable, Where such variables as the strength of the concoction as well as the dosage can be manipulated by human interference, the poisonous effects frequently vary. Factors such as the physical constitution of the Individual, the expectancy of the individual to be affected by the poison, and the length of time between doses may be considered to affect the outcone of the ordeal in stich a way (that is, psychologically and undetectably) that the trial does in fact appear to be controlled by other than human agents, viz. the supernatural. It should be noted that most of the West Atlantic groups do not think of the poison used in this ordeal as being poison per se. In most cases reported, the substance drunk by the accused was not regarded as having been poisonous, but rather as having been infused with divine power which would become active as a poison if the accused were guilty. 88 Among the Temne, for example, the logic is that the sasswood specialist knows that "certain evil spirits" dislike certain herbs, which, if administered to the one possessed, will have the effect of

$$
\begin{aligned}
& { }^{87} \text { Kirk-Greene, op. cit., p. } 52 . \\
& { }^{88} \text { Evaris-Pritchard, op. cit., p. } 344 .
\end{aligned}
$$


disgusting the spirit and inake him fly away. 89 This fact is substantiated further by the fact that the names for poison are not the same as for the sasswood ordeal medicine. For instance, the Mano term for poison is wu, while the name for sasswood is gli, which fs relatea in turn to a word, gli:, meauing "to burn."

In this respect the earliest record of the poison, though in arother aspect, was reported by Cadomosto in 1455 , who stated tinat the Wolof "squeeze blcod from a poisonous snake and mix it with the juice of a certain tree and prepare the compound for poisoning arrows," at which he concluded that they sere "great magicians." 91 The certain tree coid well belong to the genus Erythrophloeum, since its use is mentioned as being a poison.

In addition, a public racord office report cites the existence of "red wood" being avallable in 1648 on the Rivers Cerbero (Sherbro), Kiddam, Maray, and Melyn within the range of the present West Atlantic tribes. $^{92}$ At this point, it is apparent that this wood was regarded exclusively as a building material or for manufacturing mortars and not for its poisonous uses, for these were not mentioned. It is significant to note that redwood is recorded at this early date and that the name has remained to the present.

${ }^{89}$ K. J. Beatty, Human Leopards (London: Hugh Rees, 1915), p. 25. ${ }^{90}$ Schwab, op, cit., p. 379.

$91_{G}$. R. Crone, The Voyages of Cadomosto (Iondon: Hakluyt Soctety, 1937), p. 45 .

${ }^{92}$ Cinristopher Fyfe, Sierra Leone Inheritaice (Jondon: Oxford University Press, 1964), p: 60 . 


\section{THE SASSWOOD SPECIALIST}

Another characteristic of the sasswood ordeal is the presence of and participation of the legal-religious specialist in the administration of the trial. For the Dan, G1o, Mano, Loma, Geh and other groups of the west Atlantic cluster, this individual represents a class of special elders called zo, who are the hunters of witches and social "police" authorized by the Poro and who own the most powerful "medicine" for catching witches. Any blg zo is supposed to know about both poisons and witchcraft. 93 In other tribes, such as the Kru, the specialfst may be a revered eldex, but he is not the Iocal chief or the Iineage head. 94 Among other West African groups outside of the West Atiantic ciuster, he has been called an "oath swearer"; and often confronting a persos "wth one of these dreaded specialists is enough to induce him to present additional evidence or alter his statement." 95 in any case, only men who know medicine, especially sasswood medicine, well and themselves possess strong medicine can conduct the ordeals. 96 In addition, he mist be able to remain sensitive to public opinion regarding the fate of the accused because the final authority over the administration of the poison ordeal rests in the specialist's hands in that it is he who determines the dosage and the condition for tine trial. Since the sasswood

${ }^{93}$ Schwab, op. cit., p. 374 .

${ }^{94}$ H. Bridge, Journal of an African Cruisei (London: Dawsons, 1845).

95 H. Huber, "Ritual Oaths as Instrutents of Coercion and SelfDefense among the Adangme of Ghana, "Afyica, XiX (1859), pp. 41-49. "Sohwib, op. cit., p. 428 . 
practitioner has such controj over these and other considerations of the trial, it may be sajd that tine will of the spirits in this legal natter is less important and determinative than the act of the specialist, who may be considered to be the actual judga.

\section{THE ACCUSERS AND THE ACCUSED}

Conditions wich require the performance of the sasswocd ordeal are a product of the nature of the accused and of the accuser. In orier for a trial to be perforned, one has to be accused of "high crimes" as they are defined for the various West Atlantic tribes. Before discussIng the speciflc crimes which necessitate the ordeal by sasswocd or oathswearing, one would do well to consider the general nature of the accusations in relation to the legal systems of the groups of the West Atlantic cluster.

In general, the accusations of the social high crimes are arbitrary in that they are not usually directly related to the actual guilt of the individuai accised of the crime. Unless the guilty party has been caught In the act, anybody is potentially accusable of the crime. On the cther hand, accusations are highily selective in other respects. ${ }^{97}$ Thus, depending on the group concerred, kin may be exempi from accusations by other kin which would resijit in the submission to the sasswood ordeal. The specific crimes which are subject to the sasswood ordeal include four scctal transgressions among the West Atlantic groups: adultery, murder, witchcrati, and less irequently theft. Witchcraft constitutes perhaps the greatest number of such accusations.

${ }^{9 T}$ Glucikniar, op. cit., p. 269. 
Witchcraft has been cited as "an almost, if not completely, cultirally universal explanation for 111ness, injury, and unexpected and unexplained deaths." 98 Indigenous systens of causality 3llege that most Eorms of physical and psychical disoraer are inexplicable in terms of natural causes, such as infectious diseases, psychosomatic complaints, and metabolic disorders. In addition, in the West African reilgious and ideological framework, no death is precisely natural. 99 Even the death of an old man of 95 years will be explained by the intervention of witches: it is taken for granted that the old man would have died eventually, but the question of the manner of $\mathrm{r}_{i}$ is death, the precisa time and place of death are considered as evidence that the death of the individual had been manipulated by a witch. In addition, even natural calamities such as drowning and other accidents are often not interpreted in terms of natural causation; and in all these cases, witchcraft is viewed as the instigator of the trouble. It is thought that accusations of witchcraft make it possible to allay diffuse and unnamed fears which might otherwise result in neuroses and societal dysfunction. 100 In this sense, accusations of witchcraft serve "scapegoat" functions.

Following this iine of reasoning, accusations are defined as a simple projection of repressed hostility; that is, one blanes another for his own faults and the object of the accusaticn usually appears to be one of whom the accuser is jealous, for whatever reasons. 101 In

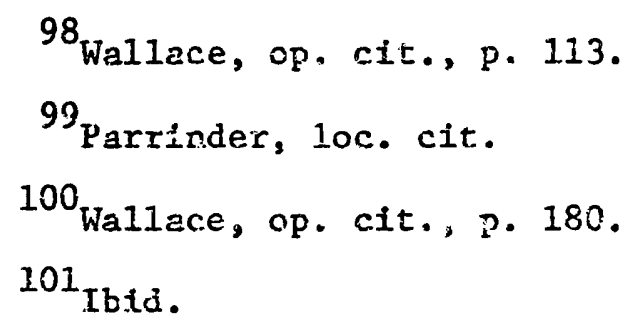


keeping with this notion, it has been noted that "the prevalence of ard accusations of witchcraft seen to be determined both by the naturai cleavage lines in the socicl structure and by the success of the society In hanuling conflict by such secular wearis as court procedings and arbitration." 102 It wil1 be noted latex that social position is important In ascertaining who will be accused, as well as the efficiency of the group in bringing its accusations to fruftion. Shere these methods are not efficient, that is, vhere the guiliy are not known, the likelthood of accusations not based on the existence of "evidence" would increase. In this aspect, it has been roted that "the fear of witchcraft should be regarded ... In socketies without courts of law, as a principal means for maintaining standards of widespread conformty to conventional, nonexploitive standards of propriety in interpersonal relationships of alI kinds." 103

Basically, the purpose of accusations, especially of witchcraft, Iles in the social necessity to achieve a new balance of power and wealth within the society. The schism into factions resulting from the public accusations extant in the group arises partly out of personal ambitions and partiy out of self-interestediness in some of the members of the society. 104 That is, one who is envious of another, whether through the Iatter's wealth, social position, or political achievenents, will blame him for the forner's bad luck, Such a function may be regar-

$$
\begin{aligned}
& 102 \text { Wallace, op. cit., p. } 182 . \\
& 1.03 \text { Waliace, op. cit., p. } 184 . \\
& 104 \text { Gluckman, on. cit., p. } 272 \text {. }
\end{aligned}
$$


ded as roughly similar to gossiping in peasant socleties. In that case, indfviduais "think of their universe as one in which the good things in life are limited and in unexpandable quantities and hence personal gain must be at the expense of others: "105 These social-equalizing functicns would be practical as more than a mere tension- and gruagereliever. By being accused of witchcraft or murder or otherwise belng the focus of soclal disaprobation, the wealthy or powerful indjvidual. may be forced to relinquish all or part of his wealth if found guilty: and in any event would necessarily have to pay a legal fee to the specialist in the form of slaves, wealth, or servicas. 106 Thus, accusations nade (or the possibility of their being made) in connection with the sasswcod ordeal are seen to have a social equalizing effect. Substantiation and further discussion of this purpose will be considered in a later section.

Adultexy presents as a class of crime which may be regarded as essentially contrary to the stability and cohesion of the group by exacerbating existing rivalries as well as promulgating new ones. Tris attitude has been seen as another manifestation of the "traitor within the gates" notions described for witchcraft and murder. ${ }^{107}$ Note will be made of the adultery case settled by sasswood in the Dan myth.

Two sources pointed cut another condition of the use of the-sass-

${ }^{105} \mathrm{G}$. Foster, "The Image of the Limited Good," Peasant Society, Ed. G. Foster, M. Diaz, and J. Potter (Boston: Little Brown and Co., 196\%), p. 300 .

106 Afzelius, op. cit., p. 25 .

${ }^{107}$ L. Naix, "Witchcraft as a Problem in the Study of Religion," Cahiers d'Etude Atricaines, IV (1064), pF. 335-348. 
wood orjeal which would broaden the witcheraft classification to include nembers of the Leopard Society in Sierra Leone and Liberia. Strong 103 and wilson ${ }^{109}$ repoxted thiat men accused of Leing nembers of the Leoparc Society--a speciai class of witch who fractised human sacrifice and were thought to change into leopards at night ${ }^{110}$-were required to submit to the ordeal and usually confessed after the first draught. In keaping with national laws now in existence, the guijty vere sentenced to hard labor for 1 iff rather than being killed. No record of the Leopard Society appears to have been made before 1856 , and it nay be regarded as an "underground" movement for meting out indigenous vengeances other than through white 1aws. Lady Dorothy Mills reported that this purpose of the sasawood ordeal had been used since "time immemorial."111

\section{V.' ORIGIN MYTHS}

As mentioned above, the laws, morals, codes of conduct, and ethics of a group are bound to the supernatural in the mythology of a society. Origin myths answer questions on the mannes in which the world began and serve to establish an order among values and to justify, by reference to these values, the major customs and institutions of the society. 112

${ }^{108} \mathrm{R}$, Strong, The African Republic of Iiberia (Cambridge: Harvard University fress, $19 \overline{30}$ ), p. 103 .

109

, Wilson, op. Cit., p. 193.

110 Beatty; op. cit., p. 14 .

${ }^{111}$ Lady Lorothy Mills, Through Liberie (London: Duckworth Press, 1926), p. 125 .

112 Wallace, op. cit., pp. 57-58. 
This ciassifiration of myth would include those on the origins of the legal-religious procedures such as the sasswood ordeal; and as part of the oral tradition, they are one of the methods by which a researciler may gain Information on the history of and development of a certain practice. To date, the oniy recorded complete origin myth for the sasswood ordeal has been provided by a German chroniclen, Eberhard Fischer. In his interpretations of the oral traditions of the western Dan group in Liberia, Fischer noted correlations between the origins of witchcraft, witchhunters, and the secret society of the Dan and the problem of death by poisor and adultery. He concluded that poison was initially developed for the purpose of solving the population probiem by aliminating the elderly who are past their productive ages which would prove an economic drain on the younger members of the soclety. God (Xra) gave the Dan "leopard poison" (ge du), and it was placed in the hands of a speciailst who was an "esteemed old person."113 The possessor of the poison with his ge du lived in a hut built just for him and distributed the poison only "when the majority of the people so desired."114 In this case, the poison is intended to act to counter the resource drain by kiliing the elderly. In addition, one can see a secondary function in that the young are able to balance out the influence of the elders by being abie to "retallate" aguinst them. At least, so goss the legend.

The following translation of the remainder of the origin myth demonstrates the relationship between the secret societies as agents of social contrel and the instigation of the sisswod ordeal.

${ }^{113}$ Fischer, op. cit., p. 695. ${ }^{114}$ Inid. 
The eiders were therefore poisoned so that the young could have a comfortable place so that they could settle there.

Once the people had settled down to such an existence, two wealthy men called bedumd lived together in the village. Each was a lineage head. They were both mastets in their village. The chief wife of one had fallen in love with another lineage head. She persuaded the stranger to secretiy steal a suall piece of the ge du (1eopard poison) and give it to her orm husband to eat. Tre guard over the poison was bribed, and he allowed the two of then to take a significant portion of the Ee du. They took it and poisoned the husband.

All the people in the village were disturbed by this occurence. They said, "No death could occur without ge du. We must go to Xra and get him to advise us in the death of the lineage head."

Thus it was that Xra gave men that group of people whom one calls the zo (members and leaders of the Poro secret society). These zo masters were given the seeds of tha sasswood tree by Xra. In addition, he gave them bark from the tree. And Xra said, "The zo will reveal tc you the name of the one who has stolen the ge du for his cwn purposes. Each who denies the charge must drink the sasswood draught. Plant the seeds that I have given to you. Make the draught from the bark of a fullgrown tree." In the rigit the zo found the woman and the man and charged then both with the death of her husband. The woman confessed her complicity. The lineage head denied it, and he took a swallow of the gli. (sasswood draught) as he was cominanded to do. Thus it was that he died.

That is the tale of how Xra created mar and how he introduced deati: (ga) tc them. Furthermore, it is the story of how Xra delegated special powers to certain nen (zo) such that they can hunt witches and confirm their work through the gift of the sascroou poison. 115

In the myth, certain "fdeal" aspects of the relation of sassiood to the society in general becomes evident. Most obviously the ordeal has been used for the detection of guilt and falsehoods. More specifically, the principal crine was the misuse and abuse of the divinelybequeathed ge du for arti-social purposes, such as aduitery. Corruption 115 Fischer, 10r. cit. 
of the ge du guard is evident and may be regarded as a further sign of the moral decline of the commotity. Furthemore, the care and administram tion of the sasswood is under the direction of the zo, or legal-religious representative of the Poro secret society, and thereby a distinctive "policing" iunction has been estabilstied.

Though the principal crime comitted in the myth appears to be adultery, so should one also take notice of the fact that murdex was conmitted to attain the liafson. That is distinctiva in this case is the fact that the murder was committed by a poison which was given by Xra making the crime doubly heinous. Though tt is not mentioned in this nyth, witchcraft crimes constitute the other special focus of the use of the sasswood ordeal.

By virtue of the fact that the myth had become part of the oral tradition, by the time Fischer reported in 1967 , one can infer that such supernatural sanctions manifested through the practice of the sasswcod ordeal still present a viable part of the Dan legal and moral code and that these divinely ordained practices function still as punitive measures. Indeed, the tone of the tale is not "this is what our people used to think", but rather "this is how we thinis today."

Similar reports for other sasswood-ising groups outside the Hest Atlantic cluster sulstartiate the probabie origins of the complex in the users' eyes. Among the Adangne of Ghana, for example, old people, particularly functionaries acting as representacives of the tribal soirits, state that people used to be respectful, humble, and trustworthy. As a resuit, they say, the people grew oid and deaths as a result of magic (we Eem) were rare. Later with the moral slackening of the society, 
it became recessiry to inyoke striefer sunctions by means of ordeals aria caths, and tilereby, crder, athority, and justice were preserved. 116

Cnly one provert related to sasswood has been reported, and it is for the Mende. "Ba bi bunde b:1, bia ti gole a gbou," has been trasiated as "If you are unier the sasswood tree, your skin will become red."117 This may be irterpreted as a statement that tha sasswood makes cre's guilt evidenc; that is, it incriminates the guilty.

\section{INTRACULTURAL CORRELATIONS}

The oath-ordeal complex does not exist as an independent encity or as some cultural quirk. Correlations with other aspects of culture should be considered in the functional study of the complex. As noted above, oaths and orceals may be seen as solemn, formal "tests of faith" In the determination of guilt or innocence in the face of specific accusations. It should also be remembered that caths and ordeals are qualitatively different. These differences have been related by some authors to other cultural aspects including political organization: social structure, economic conditions, and child-rearing practices, 118 It is the opinion of this author that child-rearing practices form a most significant factor in influencing the existence of oaths and ordeals and that socializarion is affected in turn by the cher correlations.

${ }^{116}$ H. Huber, op. cit., p. 47.

${ }^{117}$ F. M. H. Migeod, A VLew of Sierra Leone (London: Kegan Faul, 1926), p. 277 .

${ }^{1.18}$ Roberts, op. cit., p. 186. 
Economic CorreIations

According to John Roberts, the spectfic occurence of either or both aspects of the oath-ordeal complex has been ijiked statistically with spectfic economic modes. ${ }^{119}$ The groups of the West Atiantic tribes primarily subsist by agriculture with shifting swidden cultivation and fallowing, with principally rice, cassava, and other Malaysian crops. 120 In addition, sinali stock is kept, though a few cattle are retained by the people for brideprice, and the stock is not nilked. Cattie, then, may be regarded less as a "raw material" of the economic iffe, but more as an item of wealth. The complex is also alleged to be correlated with "economic complexttys" 121 which Roberts interpreted as being the existence of a money econony. This aspect is well developed among the thest Atlantic groups as a "unique type of currency, consisting of T-shaped pieces of forged iron finds acceptance over much of the xegion, ${ }^{122}$ which has been used historically. Since the majority of the groups practice both oaths and ordeals, these correlations may be regarded as being significant.

The reason for the correlation between the existence of swidden agriculture and ordeals may be a reflection of the obedience-training which would be required in tine cooperative ventures of agricultural societies (i.e., belag part of a "team"), raquiring close adherence to and obedience to the rules. On the other hand, the exclusive existence

${ }^{119}$ Ibid.

120 Murdock, op. cit., p. 261.

${ }^{121}$ Roberts, op. cit., p. 193.

122 Mirixdock, loc. cit. 
of caths witin herding may $b=$ considered as a product of individual responsibility which vould be necessary in this practice as nore autononous and independent.

It has been noted that animal domestication is thought to be associated with the practice of oath-swearfng and therefore the latter is a simpler, more "pximftive," zore basic function in its less ritualized form and purpose of direct suppiication to the supernatural. ${ }^{123}$ It may be that this is the reason for the survival of the practice into industrial Africa, especially in light of the prohibitions made by the government on the practice of ordeals.

\section{Social and Political Correlations}

In Roberts' cross-cultural investigations, ordeals and oaths were both found to be associated with communities of greater than 1000 members. This relatively large populaticn was described as having "intermediate to high degree of political organization," 124 which Roberts has interpreted to mean the range from the system of "minimal states and dependent societies" to the state level. The system among the west Atlantic tribes may be described as being of tine intermediate type, with pclitical authorf.ty on the local level normally allocated to the headman and council of eiders and petty paramount chiefs over smail districts. ${ }^{125}$ Roberts has summarized his correlation as follows.

0rdeals occur in much acre specific situations than oaths. They are found where there is something of a general, but weak, authority systen. When the authority system becomes

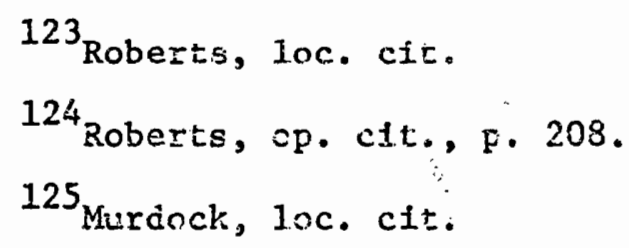


strone enough to enforce all decisions, zight or wrong, without fear of the effect on public opinion, ordeals can then disappear. 126

The power structure introduced by the Protectorate system nay also be interpreted as becoming a "stronger" political systen which could make possible the diminishmert of the ordeals in their importance.

It will be remembered from the description of the sasswod ordeal that palaver is a characteristic of the ordeal, in that the case is assessed in front of a council of elders and the local chief or headman is consulted before the administration of the sasswocd draught in order to ascertain how it shall proceed. The correlation with respect to population size and political organization may be seen in the fact that the direct control over the scciety's members is necessarily minimal; and the fear effected by the threat of the ordeal and subsequent supernatural sanctions for crimes would serve to extend this direct control. The sanctions of the ordeai compensate for the leaders: inability to deal directly and instantaneously with all possible offenders, at least In regard to key "crimes." The "violent" nature of the ordeal would stress the point of cohesion by setting an example.

It can be seen that a weak political organization is associated with the practice of the ordeals in that the fear inspired by the practice serves to "nip in the bud" the tendencies for criminal. action which would be socially disruptive, while oath-swearing would indicate a stronger organfzation where such strict punitive sanctions would not be necessary to the same extent.

$126_{\text {Roberts, }} 10 \mathrm{c}$. cit. 
A high degres of sockal stratification also has been noted in conjunction with the existence of paths and ordeals, 127 presumaily because of certain discrepancies in power or wealth resulting in most comunities which create situations of envy, enmity, and suspicion. Historicai evidence would seem to substantiate this comection made by Roberts. Afzeliue, ${ }^{128}$ Bxidge, ${ }^{129}$ and Corry ${ }^{130}$ reported that it was usually the wealthy individual of the seziety they studied who was accused of witchcraft, and it was he who had to submit. to the sasswood ordeal.

Residence, descent, and inheritance follow the patriline in 211 the tribes of the West Atlantic cluster, though very few matrilineal associations have been noted (e.g., among the Sherbro). ${ }^{131}$ Roberts has examined the data and made the further correlation between the practice of ordeals and the incidence of what he describes as being "motherchild households."132 since the women of most tribes of West Atlantic origin breast-feed their children for at least two years after birth (or until the infant walks) ${ }^{133}$ and the husband is refused sexual access to his wife during this period, the mother-child relationship can be seen to be exclusive and intimate, inculcating a dependency. Oaths are one-sixth as frequent as ordeals among this household type. This close,

127 Ibsd.

${ }^{128}$ Afzeiius, op. cit., p. 24 .

129 Bridge, op. cit., p. 67.

130 Corry, 1oc. cit.

${ }^{131}$ Ha11, 10c. cit.

132 Roberts, op. cit.s p. 195.

${ }^{133}$ Schwab, op, cit., p. $21 E$. 
dependent relationship resuits in greater bbediance training then responstbilfty training in that one has learned from infancy to do precisely what mother says and not to act independently. This would in turr. produce a greater frequency of ordeais in which case one is being punished for disobeying the supernatural and rot being honest with then.

\section{Socialization}

The most interesting correlation demonstrated by Roberts is that between the existence of oaths and ordeals and the psychological states resulting from child socialization methods. 134 In this regard the discussion at this point will be concerned with the differences extant between responsibility training and obedience training. Responsible behavior has been defined in contrast to obedience training.

The extreme of responsibility in this sense (of performance of tasks, duties, and routines which are demanded by the culture) would be found in the willing performance of laborious duties or tasks, which the child has come to carry out on his own at the proper time and can be trusted to do. It can be contrasted with high obedience, where the child may passively do what he is told or any occasion, but has not himself learned to perform duties without immediate instruction. 135

Most of the children of the groups such as the Gio appear to be trained in obedience. They are given explicit tasks at a very early age. Corporal punishnent, though used infrequently, is employed for disobedience. As an example of parental attitudes of their children's non-responsibi1ity, "the Gio state that they don't ... expect wuch heip from their

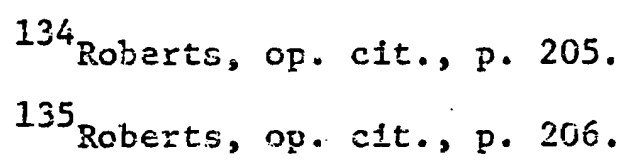


children" nor is it worth irytng to teach them before six years of age, because "they see some food, and then forget what you said."136 In addition, children are ustally under direct parental supervision for the majority of the time. The conclusion is that obedience tratning predominates, probably as a result of swidden agricuiture in that this economic mode, genera1ly, requires nore of a cooperative effort than herding. 137 The relation of oath-swearing and responstblity training may be inferred by noting that if a menber of the society can be trusted to be responsible and independently honest in social and other matters, it would seem logicai that this same trust would be projected to his legal behavior. ${ }^{138}$ Ordeals present a contrasting picture: In this case, the sanctions appear to be external, rather like the dichotomy which exists between the concepts of shame and guilt. Because in the case of ordeals, the point is to be "caught" at something by the intercession of human agents working in the "service of the supernatural," one can infer a high level of anxiety which would result in autonomic physiological responses, which would, in turn, "prove" culpability. The oath-swearer, on the other hand, has nothing to faar in terms of "natural" retribution and any justice meted out in this case would be between the accused and the sfirit to whom he swears; that is, his sanctions are "internal" in that his owa concept of crime and punishnent determines whether or not the swear will be effective.

In summary, Roberts has de:nonstrated correlations extant between

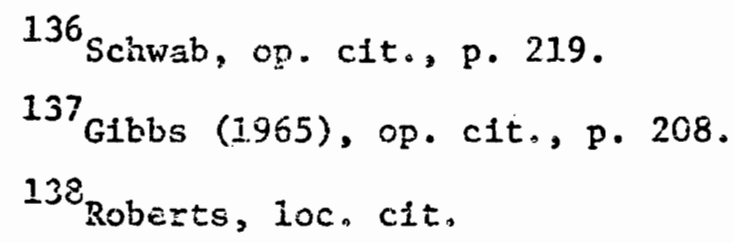


various aspects of a culture inciuding social, political, economfc, and psychological, and the differential practicinz of oaths and ordeais. By way of a nomothetic starement, these two practices appear to be generally associated with relatively complex societics, which, in the presence of somewhat ineffective authority and power structures, requfre special means for the maintenance of law and order. They are used because sheer force and techniques of coercion are insufficient or potentiaily destructive niethods.

\section{FUNCTIONS}

From a cioser readirg of the above descriptions of the characteristics of the complex, the various functions of the oath-ordeal complexs may be deduced. The functions are relevant to this study in that any approach to the study of culture change or stability requires an analysis of the use, meaning, and function as well as some understanding of the operation of the complex in relation to the whole of the culture. Cu1tural items, whather material or non"material, do not exist free-floating in a void: they are integrated, more or less, with cther aspects of the culture.

\section{As a Legal Mechanism}

Perhaps the most obvious function of the sasswood ordeal and the concemitant vaths is that of being a strfctly legal mechaniem. Such a function can be split into genuine belief on the part of its users that the complex actually functions to determine guizt ox innorence and otherwise acts as a legal agent, being at the same time both judge and executioner. The action in this case is directiy meted out by the di- 
vine and fis inmediate. The second aspect would be symbolic belief, especially ir the case of oaths, that justice will be serred in the end and that by having performed the prescribed ritual of oath-swearing alone, the case will be taken care of. In the situation of oaths, the action is delayed, but also direct. In both instances, the individual would see both aspects as effectively solving legal and moral issues to the satisraction of the society. In the case of oaths' delayed action ("general warrant") and the ordeals' Immediate action, a more complete coverage for all crimes-past, present, and future-is achieved and provides a greater legal security for the society.

\section{As a Sociaj. Unifier}

Another function closely related to the carrying out of justice is the social unifying effect of oaths and ordeals. During and after a crime such as witchcraft has been committed, there follows a period of generalized social malise and tension whose diffused focus becomes solidified in the person of the accused. 139 During the highly emotional period preceding the accusation of the individual, the society is regarded as being in a state of social and moral disequilibrium which has resulted from the consequences of the crime as we11 as the uncertainties of who is the culprit and the vulnerability of the other nembers of the group to similar attack, such as witchcraft or aduitery. By perticipa-

${ }^{139}$ An anajogovs function was proposed by Malinowshi (Magic, Science and Religion, i948: p. 52) in his noting that death in a society "threatens the very cohesion and solidarity of the group" and that raligion and the ceremonial of death "counteract the centrifugal forces of fear and demoralization and ... provide the most powerful means of reintegration of the group's shaken solidarity." 
ting In the enotional, solem ritual of oath-sutearing and ordeals, the members are sathartically relieved and the society itself returne to a state of equilitrium. This is achieved through the deliberate, public, and conciliatory actions of the ordeals and oaths.

\section{As an Equalizer of Sccial Status}

Among the West Atlantic groups studied, caths and ordeals serve to equalize inequities of social status among the individuals of the society. Some Instances were reported where men only, acting as elders, could accuse those persons of being witches. 140 'In adaition, with the exception of very rare cases in which old women were allowed to accuse others of witchcraft, females were the recipients of the accusations and were never the instigators. ${ }^{141}$ It should be noted that both men and women could be accused of witchcraft, but only men (and old women) could accuse. In keeping with the fact that witcheraft accusations, like gossipirg, are usually directad at those who invite the envy and jealousy and mistrust of others in the society, one may see that by and large it is the havenot's who accuse the have's of witchcraft. Whether innocent or guilty, the man so blamed must pay a legal fee to the sasswood specialist and must be publicly accused, thereby "satisfying" the public that justice Is being coriectly exacted (that is, that the one of whom they are jealous is being shown for less-than-mighty). Furthermore, if the party is found to be guilty, he will be removed from the sociaty through his death; and upon his demise, cases have been noted where the deceased's

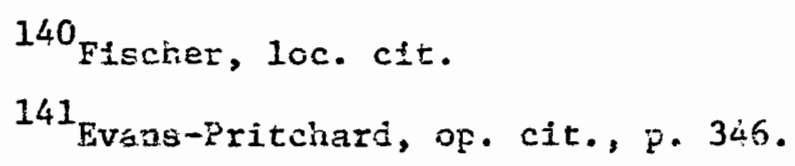


famlly is sold into slavery snd his goods redistributed throughout the soclety as a wole. 142 Fox exanpie, Moretio butige, whiting in the nineteenth century, reporten that the accused's scttie were redistaibuted after his proof of guilt and subsequent death, demonstrating the sotion of the social equalizing functicn. ${ }^{143}$ In this way, one can see that no: only are the possessions of the accused distributed on a irore equitable basis throughout the society, but also the fartily of the envied one nay be reduced to slavery, which may be regarded as being "very satisfying" to the group.

The Association with S1avery.

Arother function follows from the preceding. It was noted that in some Instances the families of the guilty wexe sold into slavery, which fact has been established in several sources. Fox instance, a nincteenth century report on the slave trade states that, "nacives also sometimes become slaves, in consequence of erimes, as weil as (the fact) that it Is not an uncomnon thing on the coast, to falsely impute crimes for the sake of seeking persons so accused of crimes. "14 $^{14}$ the crimes "falsely imputed" were aduitery and witcheraft, which automaticaily called for the sasswood ordeal. George Thompson, a missionary writing in 3.858 , described the fact that among the Mende the clifes went to war or else

142 Afzelius, op. cit;, p. $24 \mathrm{ff}$.

143 Bridge, op. cit., p. 68 .

$144 \mathrm{~b}$. O. Blake, The History of Slavery aris tize Slave Trade

(Columbia: J. and i. Miller, Fublishers, j858), p. il3. 
brought false charges against the individuals in order that they thight be sold into slavery. ${ }^{145}$ John Mathews inade reference to the fact that the penalty for appaxently even an accusation of witchcraft was "slavery Inevitable." 146 These citations indicate 3 further consequence of the ordeal in the intensification of the slave trade which dominated the eighteenth and nineteenth centurjes. It rould appear that supernatural approval of the Increased wealth of the accusers was given in exchenge for bringing so many "miscreants" to justice. Analogies niay be seen in the Protestant (Calvinist) ethic of God's will and favor being manifested in the eccromic success of His flock, just as those who were successful in the slave trade became economically well-off because of their performance of "justice" through ritual means.

\section{Politics anci "Police"}

The relation of the Poro secret society and the existerce of the sasswood ordeal manifests yet another function of the ordeal: political control and a "social police force." As noted in the Dan myth, the witch-hunting activities were assigned to the zo, or legai-religious specialists. As reported in Harley, all inajor offenses against the society or sgainst the Pcro, including nurder and witchcraft, would be subject to a trial that was held by the $\mathrm{Ki}$ La mi society in secrecy, so that society secrets would not be reveaied to the public. ${ }^{147}$ The

${ }^{145} \mathrm{G}$. Thompscn, The Palni Land (Loncon: Dawsons, 1858). ${ }^{146}$ Fyfe, op. cit., p. 92 .

${ }^{147}$ G. Hariey, Masks as Agents of Soctai Contro1 in Northeastern Liberia, Papers of the Feaboty Museuri of Anerican Archaeology and Ethnology, volume XXXII. No, 2, (Cambridge: Harvard Jnjuersity Press, 1947), P. vili. 
sentence, trial by sasswod or execution, would occur at a later date fo public. This demonstrates lht tir poro slso used the sasswcod ordeal for its cwn purposes.

Perhaps the best way of showing the relaticnship between sasswook and the administration of justice and the applfcation of polfitcal pover would be to quote Larley. In describing the Poro anong the Gio, he states that:

... There vas a tendency to minjpulate the mechanism of justice and its execution so that no cne wotid appear publicly responsible either for the decision or its execution. The best example of this is the sasswood craeal, in which the poison cup drunk by the acclised was supposed to make its own decision automatically, If the individual were guilty, the sasswood executed him on the spot with the same infallible mechanism. There was no judge to be the object oi resentment of those who dissented ... To make the whole thing still further impersonal, the sasswood ordeal was presided over by an individual whose idontity was hidden under a great mask, representing not an ancestor, but the great forest demon. The idea was inherent that it was on this authority that this trial was conducted and that he had made this public appearance for that specific purpose. There was also the idea that the poison portion was the real judge of the guilty. A detall of the sasswood ricual refers the whole responsibility to the tree itself.

In the sasswood ordeal we have mask, medicine, and mechanist. all sharing the blame. My use here or the term "medicine" perhaps needs modification. It is reajiy mana, or hidden power inherent in the drug, which does the work. The mechanism is merely to put that power into operation and to protect it fron the contrary forces or powers that wovld tend to neutralize it; for it is well iecognized that if the mana of any substance falls to work, it is either because there is present a more powerful, opposing mana, or because the ritusl mechanism has not been properly carried out. in the case of the mask, the inherent mana should be considered as the most powerful possible. 148

It may be deduced from the quotation that the zo manipulated justice in that by substituting the mask as the agent of soctal control such that ${ }^{148}$ Harley, op. cit.s p. Lx. 
the indfyidual acting in a legal capacity is able to remain in a position where be does not have to accept the consequences of these juristic actions. Their knowledge of the beliet systems of the scciety that dictates those situations that will require the sasspood ordeal as weil as their knowledge of the poison's varying action result in a position of authority in thet it is they who, in effect, "wojte" the rules. Masks In the Porc secret society serve the purpose of makirg distant the association between the human agents (zo) and the effect of the judgwent. manifested through the actioin of the poison.

The other than political-legal functions of the Poro wili not be considered at this time other than to note that the Poro

forms a very powerful and secret organization to control all its nembers. The leaders of the society hold sway over corimon men, impose laws upon them, and keep then in check by the fear of the supernatural powe $\mathrm{w}$ wh which they are believed to be endowed. This fear lies belifid all heacis of families and men of standing, behind all chiefs and political leaders. 149

The Poro secret soclety, or the equivalent, exists among all of the West Atlantic tribes and has been described as ore of the characteristics of this culture area.

There are numerous historical references to the Poro society. The earliest mention was in 1560 in the report of an Englishman, John Hawkins, who sailed by the West African coast. What he termed the "contuberia" judged the cases of adultery among the Tenne. ${ }^{150}$ According to Hawkins in these cases, swearing was done to the spirit of the Poro, so. that: there is evidence for the early association between the Poro and oath-

$$
\begin{aligned}
& { }^{149} \text { Hariey, op. cit., p. } 30 . \\
& { }^{150} \text { Fyfe, op. cit., p. 34.5. }
\end{aligned}
$$


swearing.

In 1620 olfert Dapper waid reference to the extstence of the "Pelli-Paaro" (or Poro) society which tried witchcraft and adultery casas. AlI unexplained deaths were attributabie to witchcraft, and cue may infer. that the sasswood ordeal, or oath-swearing, vere ased to detect the cur... pability of the accused individuals. ${ }^{151}$. The Mano and Loma name for the secret society is bele (or "Be11i"), which would seem to substantiats Dapper's observation. 152

Renneth Little in 1955 stated that the secret societies were in the possession of the strongest meaicine used in swearing. 153 while other "unofficial" medicines were extant aning the Mende, the only reai, genuine, and official usage was of the foro medicire.

\section{As an Educational Tool}

The final function of the sasswood ordaal tay be regarded as an educational tool; and in this capacity, it is reiaced to the operation of the Poro suciety. Where the Poro is meant to provide for the indoctrination of the boys in tribal lore and custoin, the legal-rallglous aspect of the Poro-sponsored, zo-conducted sasswood ordeals serve to further inculcate the audience with moral lessons about socially defined "grave matters." This may be construed as pcssessing a mnemonic function.

${ }^{151}$ o. Dapper, Jmbstündlic. Be und Eigentliche Beschreibung von Afrik: (Leiden: Jacob von Meurs, 1620 ).

${ }^{152}$ schwab, cp. cit., p. 486.

${ }^{153}$ Kenneth Little, The Mende of Sierra Leone (Londong: Routjeage and Kegan Paul, 1954), p. 129. 
This does not nean that the individuals are toda, in a "coded message," that cercain actions are detrimental to the society and are therefore iliegal. The effect is less obvious. Like the trauna of circumcisicn and subincision, the pain associated vith the poison ordeal may be said to function to ingrain the principles into the recipients', and the observers' minds. ${ }^{154}$ Something that is either painful or associated with pain in the accuseds' and audjence's eyes 'is not easily forgotten. The sasswood ordeal reminds the individuals in a society that the consequences for misbehaving are painful and will be exacted for transgressions of the moral code.

Chapter IV in dealing with manifestations of resiliance and change in the ordeals and oath-swearing among the West Atlantic groups will reconstder these functions in light of past and present conditions.

154 Peter Fart, The Indians of North Americe (New York: Avon Eocks, 1968), p. 100. 
CHAPTER IV

HISTORICAI, INELUENTES

AND MANIFXSTATIONS OF CHANGE 
CHAPTER IV

\section{EISTORICAI, TNFLUHCES}

AND MANIFESTATIONS OE CHANGE

Before discussing the manifestations of change in the sasswood ordeal and possiule motivations for those chatiges, ft seems appropriate to discuss at this point generally what might be factors which could be regarded as variables in effecting change and the likelihood of such change with respect to these variables. Preconditions of culture change are especially pertinent to the case such as the present one where one trait-complex is being considered. It has been noted earljex that cultural elements are thought to change with greater rapidity and more facilely than systems of traits or complexes, so that the present study makes it even more Important to study the impetus to change as well as the probabillity of change. ${ }^{155}$ We shall begin by reiterating the characteristics of the sasswood ordeal with a view to ascertaining its vulnerability to change.

\section{CULTURE CHANGE AND THE CRDEAL}

The sasswood ordeal and its coincident oath-swearing belong to the classffication of cultural behavior described as iegal and religious, which in turn have been delineated as one of the srucial. "basic main-

$$
{ }^{155} \text { See Page } 4 .
$$


tenance, security, and interaction systems of a cilture." ${ }^{156}$ The ordeat is nacessary to the people practicing it becaube of its ability to soive problems of the society, wh th espectal regard to morality and group rules, which would otherwise result in states of disequilibrium in the face of their irresolution, necessarily hernful to the society's cohcsion. The sasswood ordeal would belorig to this classification.

The essentials of ideological security (that is) basic intellectual and reljgious assumptions, and interpretations as to the existence, power, providence, morality, $w \in I$ fare, and attendant emotional tensions. Perhaps most consistently stable have been those beliefs and behaviors which become active at times of extreme crisis and insecurity, as with natural calamity, accident, sickness, death and disposal of the dead, or the spiritual threat of pollution, as with black magic. 157

In addition, these essentials of ideological sacurity are described as being tempered with emotional overtones which justify their existence. These emotions usually are associated with the "essentials" from the time of child-training; and due to these factors of deeply engrained emotional "knowledge" of the correctness of such practices, they are thought to be especially resistent to change. In the case of the sasswood ordeal, the elements which would tend to remain stable because of the above defined characteristic of being "essential," are the use of the poison ordeals in the light of "drinking fetish" in which the draught is thought to be suffused with supernatural, divinatory power of its own; its use in the finding and punishment of witches who form an integral part of the group's criminals, reflecting as they do a "projection" of the deviant element of the society ${ }^{158}$; and finally its importance

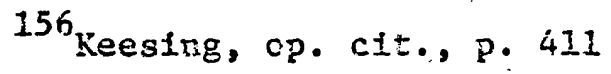

157 Ibid.

${ }^{158}$ Wallace, op. cit., pp. 177-187. 
in being a pubilc trial in thich the social. consensus is obtained. Enabuea as the sasswod ordeal is with symbelic aearing and assuring 1ts ritual form, it may ve postulated that a change in the basic strueture of the ordeal-its function less than its form--rould be either very slow, non-existent, or, at the other extreme, revolutionary due to ramant: proselyzation by a conquering peoples, in which case retntegration of the society with respect to this one trait-complex would be difficult to achieve. Because of the ordeal's close link to legal and religlous Iife, it may be generally assumed that the ordeal would tend to remain constant through time.

What impetus there has been to change among the West Atlantic tribes may be regarded as a consequence of contact diffusion, as cpposed to internal invention or innovation. Two variables, again defined by Keesing, In particular seem to be important in this case of the sassiroca ordeal. ${ }^{159}$. General flexibility of the recipient culture is significant: In that its total composition--its rigidity or its malleability--in all aspects are critical to the determination of whether the society wiil accept the adjustments. Wich regard to fiexitility, it would appear that the West Atlantic tribes are split. The coastal tribes seem generally less rigid"and more open to change as 2 result of their longer history of continued contact with western European nations; and in sone senses, such as econonic, these connections may be characterised as being interdependent. The 1riand tribes, such as the Dan and Limba, inay be considered to be more inflexible in their response to outside con-. ${ }^{159}$ Keesing, op. cit., pp. 390-391. 
tact because of the relative inaccessibility to these regions from the coast: and one therefore my expect greater conservatisn in their value systems.

The other variable is related to flexibilfty and has been cailed congruence of the culturai systems-in contact. 160 there the first related to the general receptivity of the host culture to innovations, the concept of congmence reflects the amenability of the two cultures to exchange; that is, are the two value systems of the Inglish, for example, compatible with those of the Temne, such that the latter would be likely to respond favorably to legal-reilgious innovations proposed by the former. It is in this regard that the innovations may come across a bulwark, for the moral systems and religious beliefs of the two are essentiaily at odjs. Where econornic and poljtical practices may be said to be complementary, the essential values of the two are significantly different. As results of westernization, where innovations in the aconomic sphere (increase in slavery, the "job" system, and the like) and in the political arena (closer contact between the individual and the local political leader) would be acceptable, the religlous and legal innovations, such as those proposed under the anti-witcheraft Christian belief systems and western "ratıonal" law of triai by jury without supernatural assistance, wuld not be regarded to be compatible with the Indigenous systems of religious and legal causality Thus, the resiliance of the sasswood ordeai in the face of Iaws estabilshed with the formation of the Protectorate ard the zenlous desjgus of the missionaries

$$
{ }^{160} \text { Ibid. }
$$


appeare seif-evident. In kesping with the above-mentioned conservatiaü of the iniand tribes, these may be considered to be especially conservative areas.

\section{HISTORICAT, INELUENCES}

There have been histcrically four critical influences which st ther. affected or were in a position to potentiajly affect the sasswood ordas. and oath-swearing. As implied in the last section, some influences have had a minimal effect, and no factors affected the practice to a very great extent. However, in all cases it was apparent that what change that was manifested was rnore in terns of form than in function and of ten one element came to dominate the other elements, giving the complex a different appearance, such as oach-swearing taking precedence over what became the illegal use of ordeals in modern Liberia. ${ }^{161}$

\section{Islam}

The earliest potential effect on the oath-ordeal complex vas that presented by Islam. Islan entered the West Atlantic region in the eleventh through seventeenth centuries by means of the spread of the Islatric Mandingo and the Fulla cierics and traders, and it was concentrated in the nurthern regions of this area. In addition, it has been noted that the existence of north-south trade routes, resulting from tcpographical featires such as thick forest which ilmited east-west trade, had the effcct of increasing the Islanic influence in these directions ${ }^{16 I_{\text {Strong, }}}$ 16e. cit. 
rather than east-west. 162 The greatest percentages of the practice of Islam are for the Susu (80 percent), the Yaibnia (40 percent), the Teme (33 percent), with the Viende, the Limba, and the Sinerbro-Krim-Bulion (averaging 5 percent each) $0^{163}$ Islamic influence has also been noted for the VaI, the Kpwest, the Kra and the Gio, though no specific percentages have been made available. 164

Many of the connections are demonstrated by linguistic affinities, such as the Vai, Limba, Susu, and Yalunka worc for sacrifice (saraka), borrowed from the Arabic. ${ }^{265}$ The Grebo and $\mathrm{Kru}$ grigri is thought to be a Krio form of gresh, an Arabic tern meaning "to drive away."166 The term for spirits--yina (Susu), L'iena (Yalunka), and dyingange (Mende) -are derived from the Aratic jin. 167

In all cases, the Mandingoes and the Euilas were respected and generally regarded as being superior to their host tribes. ${ }^{168}$ The inhabitants of the West Atlantic area admire Islam for its Iearning, the ability to make charms, and in their methods of divination as well. as

${ }^{162}$ Ruth Finnegan, Survey of the Limba People of Northern Sterra Leone (London: Her Majesty's Stationer's Office, 1965), p. 15.

${ }^{163}$ M. McCulloch, The Peoples of the Sierra Leone Proectorate

(London: International African Institute, 1945), g. 84.

164 Johnston, of. cit., p. 1067.

165 Johnston, op. cit., p. 1063.

${ }^{166}$ Corry, op. sit., f. 61.

167 McCulloch, cp. cit., p. 45, p. 70.

${ }^{168} \mathrm{~J}$. Spencer Trimisgisam, The Influence of Islam on Africa

(New York: Frederick Praeger, 1368 ), p. 4 . 
the prestige associated with this religion. 169 To this latter aspect and to the problems of African and folamid lev the reader will now be directed.

The effect of Islam on both the Iav and the religion of the tribes might be regarded as variable because of the gradations in penetrance of the religion. In Sierra Leone and Liberia, Islamic law has been amalgamated into rather than entirely replaclng native customary iaw. 170 Its effect is therefore partial, and one manifestation is the "winking at" a wealthy man of the west Atlantic cluster who has nore than four wives, a Muslim restriction not enthusiastically or completely enforced. Islamic legal tenets are based on the Sharia, which follows the teachings of Malik Ibn Anas as a type of revealea law. ${ }^{171}$ It is concerned mainly with questions of divorce, marriage, inheritance, guardianship, and vagfs (charitable trusts) and minimaliy with crimes. 172 However, though it does not mention what to do in cases of murder, the Sharta "frowns severely on all forms of sorcery and witchcraft."173 One ray see that with regard to witchcraft-caused murders, which would inciude most deaths in African ideology, the clash with traditional African

169 Johnston, op. cit., p. 104.

170 . M. D. Anderson, "Relacicasihip between Islamic and Customery Law in Atrtca," Journal of Af ican Administration, XIX (1969), pF. 228-34.

171 J. H. Price, Poldtical Instimutions of Nest Africe (London: Hutchinson Educationai. Press; 1967), F. 191.

172 N. J. Erooke, "Native Curts in Sierra Leone," Journal of African Administration, VI (1954), fp. 185-193.

1733. Davidion, A History of West Africa (Garden City: Anchor Books, 1966), ₹. 184 . 
principles of law has been fundamental. Where the tribe had been Musidmized, as among the Vaf. and the Gio of Ijberia, shere ceased to exist the reliance on fetishes, made in the African nanner in the likeness of living things; but the beliefs were transferred to verses from the Koran, where the temporary repository of the spirits was then thought to be situated. 174 The shift in legal matters is also seen from ordeal divination (sasswood) to a form of oath-swearing where the medium becomes the verses of the Koran. With respect to divination of unknows, sand. divination (kaesant) and the casting of stones (anglere) have become the chief mechanisms, so that it would appear that the notion of "drinking fetish" has been removed from their ideology. ${ }^{175}$ The fatal potentiality of the sasswood ordeal was also removed, because this practice was not In accord with the principles laid down in the Koran.

The success of the adoption of Islam by the tribes of this region may be explained by several factors. Usually, because of the prestige associated with the rellgion, it was inftially the ruling families who became Islamized and this did not involve any real change in the customary religious practices. 176 In addition, stress was laid on the uniqueness and exclusivenss of the Islamic practices and its opposition to the prevalling religion of the regions. For these reasons, of prestige and "aloofness" asscciated with the practice of Is1an, the penetration of this religion may be seen as being incomplete. It should be further noted that Is In was successful because it was effectively integrated

174 Jchnston, op. cit., p. 6.

175 Dorjahn, 1oc. cit.

${ }^{176}$ Trimingham, op. cit., p. 39. 
into traditional tenets of Afzican custom, such as poiygyry, the brideprice and divinatory procedures. The sliccess of Islan in Africa, though incomplete, may be summarized as follows.

The difference between Islam as an impersonal and abstract system with a body of doctrine and a rigid legal code embracing not merely ritual, but every aspect of life and the diversified and complex African systems of life appear so profound that few points of contact seem apparent and the psychological shock of religious change to be as great as that for an African converted to western Christianity. This is not so in practice. The reason is that Islam in contact with Africans is characterized by a series of gradations which act as insulation in passing on Islamic radiation gradually to animist societies. 177

Apparently, Islam offered some new alternatives without displacing the old, such that divination and oath-swearing could remain. In addition, sanctions of behavior found a new source in the written laws of Islam. $17 \mathrm{~g}$ The effect of Islam on the religion of the West Atlantic tribes roey be seen to be basically minimal since it blended, or was congruent, with customary beliefs.

\section{Slavery}

It has been reported that the institution of slavery was native to West Africa before the first slaves were taken in the early sixteenth century by the portuguese. ${ }^{179}$ It has remained a viable indigenous practice lip to the present among groups of the West Atlantic cluster, such as the Mende. 180 It has also been noted in this paper that the ircrease in demand for slaves by the Portuguese and the Eng1ish may have

$$
\begin{aligned}
& { }^{177} \text { Ibid. } \\
& 178_{\text {Ibid. }} \\
& 179_{\text {Wilscn, op. cit., p. } 35 .} \\
& 180_{\text {Murdock, op. cit., p. } 263 .}
\end{aligned}
$$


led to an increase in the practice of the sasswood ordeal for the purpose of obtaining nore siaves, The question may be asked again, what effect did the institution of siavery have on the practice of the ordeal? In this regard, the study will lead to an assessment of the records of the antebellum South to ascertain if the ordeni were practiced in those regions to which the slaves were shipped; and if it and the oaths were practiced, the changes and similarities which were manifested.

No question can be raised that the slave trade had a traumatic effect on the captives as well as on those who remained in Africa. Whexe those at home were faced with the loss of manpower and the increased warfare consequent to the rise of slavery, ${ }^{181}$ those who endured the Middle Passage were faced with new surroundings and new ways of life. The greatest trauma recorded was that of the lack of a basis for status among the slaves. ${ }^{182}$ It was pointed out that all levels of society were made slaves, and thus they were al.1 reduced to the lowest rung relative to their captors. It became difficult, however, to stabilize an endogenous hievarchy. They were well eware that they were slaves, but the stigma attached to this new status appeared to be not so great as the white masters' view of their position. Africans, in short, had been used to hard work and the land they were required to work were very like the lands they had left In Africa. The shock of slatery was not economic, but mainly social in the disxuption of familieg and the new chaos of their relative soctal positions with respect to each other.

${ }^{181}$ Davidson, op. cit.

$182 \mathrm{~J}$. RIassingame, The Slave Community (New York: Oxford University Press, 1972), p. 10 . 
The new "slave personality" that resulted has been described as a "result of the Linteraction between certain universal elements of West African culture, the iristitutionalized demends of plantation life, the

process of enslavement, and the creative response to enslavement." 183 With respect to religfon, it was noted that most religious practices of traditional African society were amenable to the later dictates of the white masters in their belated and haif-hearted attempts to inculcate Christian beliefs. ${ }^{184}$ Religious activities were areas of considerable potential creativity and social strength; and the slaves in the new world used religion as the central area for the creation and re-creation of the community. 185 In addition, African siaves in the new worid had come from societies in which there was no apparent distinction berween the sacred and secular activities, ${ }^{136}$ such that these facets remained integrated in the slave societies.

There are two sources of evidence which cite the continuation of the practice of poison ordeals with slight variations in the slave states. It was reported that the slaves of Virginia, for example, were known to hold "conjur talks" (i.e., palaver) before the adminfstration of "herbal poisons" in their own legal cases. 187 These poisons were effective because of the slaves' belief in their efficacy, and they eventually were made illegal of the State of Virginia in the early eighteenth century.

${ }^{183}$ Blassingame, op. cit., p. 18.

184 Blassingame, op. cit.

${ }^{185}$ G. Rawick, The Arserican Slave from Sundown to Sun-up (New York: Greenwood Publishers, 1972$),$ D. 32.

186 Ioid.

187 J. C. Furnas, Goodbye to Uncle Tom (New York: Sloane, 1956). 172 
In perusing the records of other slave cases in the South, namely Alabaina, Louisiana, and Georgia, it ras noted that many cases of the use of poisons were recorded. For instance, the recorded case in i729 In Louisiana reported the association of witcheraft with the use of poisons. 188 One may infer from this that ordeals might have been used in ascertaining the guilt of the alleged witch. Such a conjecture seews to be legitimate because the wites at this time were not interested in the customs of their slaves; and what they would notice would be the effect of the poisoning and not the manner in which it was administered or for what purpose.

Another instance may be cited as an example of what night be interpreted as the use of poison ordeals. To prove culpability in a case of theft (for examile) among the slaves, it was noted that the suspect was forced to drink "a bottle of watex filled with dust from the grave of a recently departed slave;"189 and that if the individual lied, he would die from the draught. Because of this fact, most slaves were noted to have confessed. This aspect may be quoted more fully.

Another method of detecting thieves was with the use of graveyardidust. Siaves felt that no matter how untrue a man during the life, on his deathbed, he would tell the truth or aisk going to hel1. Thus, graveyard dust would be gathered from the grave of the slave last buried, and placed in a bottle of water. The contents of the bottle was offered to the accused. Was was rold if he took the chicken and drank the water, he would go straight to heil; and if, however, ho did not take the chicken, he would have no fear of drinking the dust. Being unusualiy superstitious, many would admit to being the thief rather than have anything further to do with the dust. 190

${ }^{188}$ H. CatteralI, Judicial Cases Concerning American Slavery and The Negro (Washington, D.C.: Carnegie Institute, 1932), p. 404. 189 Blassingame, op. cit., F. 49. ${ }^{190}$ S. FEldstefn, Once a Slave (New York: Will1an Morrow, 1971), p. 174. 
In remembering the significance of a poison orieal presented eariier in thfs peper, it was noced that "drinking fetisn" or anytining sacred in the eyes of the users constitutes the users' conception of the efficacy of the draught and that the substance is not thought to be a poison, but rather to act as a poison in the case of the guilt of the accused. Thus, the report given would seem to indicate that the practice of drinking draughts to test innocence was still alive among the slaves. Changes in the representation of the ordeals may be regarded as an alteration in their needs, i.e., from murder to theft or to include both of these crimes. It may be that the practice of oaths and ordeals may have increased in the manner of social pathology in that "neurotic" behavior, resulting from the upheaval of social status and family orientations, may have resulted in an increase of crimes of siaves-against-slaves and thereby increased the use of methods of detection of these crimes, such as crdeals and oaths. Such a situation would seem to be substantiated by the fact that a great sulcide rate was noted for slaves during the Middle Passage and during the first decades in their new lands. ${ }^{19 i}$

\section{Western European Influence}

The first explorers to the coasts of Sierra Leone and Liberia came during the early to middle of the fifteenth century. The great emphasis at this time was for new lands and new sources of the luxury comnodities of the East such as precious matals and spices. While the main intention of these voyages to distan and strange lande in Africa was the discovery and clain of these material goods, as well as slaves, there was also the

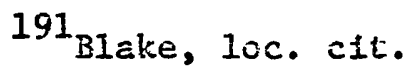


luxe of the bizarre which atiracted sone of the earlier traders. Some of these early merchants, sich as Cadonosto in 1455, were rejatively accepting and relatively non-judgmental of the stranges behaviors of the Inhabitants; bui by and large, it may be said that the earlier traders were wore concerned with ccrnerce and theix own ilinesses than with what they wrote down for posterity. For this reason: the reports during this period are concerned for the most part with physical descriptions of the inhabitants and the types of fauna and flora extant at the time. There was 1ittle concern regarding ideological frameworks or anything that was not in the most obvious sense sensational. This was the period of the Portuguese and the early British explorers and lasted from approximately the $1450^{\prime} \mathrm{s}$ to the $1750^{\prime} \mathrm{s}$. Also included in this period were the reporis of some Dutchmen, such as Olfert Dapper, who, as noted before, referred to the Belli-Paaro society (Poro).

The most remarkable description of the sasswood ordeal, both for its completeness and precision of recording as well as for the relatively early date at which it was written (1795), was that of Adam Afzelius, a Swedish botanist. His description of the ordeal among the Temne is worth reproducing for the reader, and a slightly shortened version has been placed in the Appendix. It may be regarded as the basic description with which to compare other accounts of the practice; and it is unique in the author's precision of accurate recording of events as well as his persplcacity in their interpretation.

Afzelius was trained as a botanist during the middle to late eighteenth century in two schools of though which affected the ability as a recorder. First was his instruction lin Linnean biological classi- 
fication. Where taxonotic matters were not the concern of his recora in West Africa, such a scientific training nuy be considered to have instilled in Arzelius notions of unemotional observation of and attention. to detail which would, roughly speaking, put everything in its correct place. He wrote down everything he saw, even details which others might have regarded as insignificant or superfluous. The Scientific Age and the Age of Reason were peaking in Europe at this time, and Afzelius apfears to have been the recipient of 211 the best qualities of both. 192 In addition, it has peen reported that Afzelius was a menber of an Intellectual society extant at the time called the Swedenbourg group. The main tenet of this society was the equality of the human races throughout the world, which was a renarkable notion for that period. The importance of this philosophy can readily be deduced in that it would result in even further accuracy and lack of bias in the presentation of data. This is manifested especially in his record of the redwater (sasswocd) ordeal. Fortunately, Afzelius was a true scientist, for the notion of equaljty among men did not result in romarticized, Rousseauean notions of the Noble Savage. It is of further interest to contrast the "scientism" of a Swede whose country had little or no interest in the economic advantages of slavery with the approach used by the Englisi explcrers, such as Matthews and Macaulay, whose interests in the "inferiority" of the llest African inhabitants were precipitaced by the economic advantages sought by their nother countries. ${ }^{193}$. Their "scientffic" approach resulted not in the notion of equality, but rather

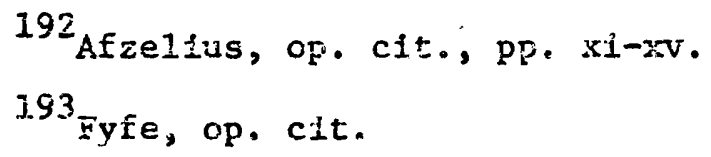


In the "proof" that the "natives" were "inferior" as presented by theit rellglous beliefs and "barbaric" practices, such as the sasswood ordeal. Afzelius was at least partially aware of the seemingly unscientific view of other Europeans when he renarked, "watching such trials provides entertainment for Europeans which they sorely resent when they are not able to see them." 194

The difference between previous recotders' descriptions of the sasswood ordeal and that of Afzelius lies many leagues apart. Afzelius. also provided some interpretation of the practice. He was the first to note, for example, the relatively arbitrary nature of the accusations made. "The real motivation for the accusations always remains a profound secret. He (the accuser) may do it upon a good foundation but also only out of spite and enmity. And the accused have no other course but to submit to drink red water."195 It may be assumed from reading Afzelius' account that the practice among the Temne and Bullom in 1795 was well established in its characteristics, and at least one of the functions at this time appears to have been as an equalizer of social status.

In the latter half of the eighteenth century up to the beginning of the twentieth century came men and women of multifarious purposes and goals to the western coast of Africa. As the attitudes prevalent at this time were many, they will be discussed in turn. Thisperiod was dominated by British influence.

The "British mentality" at this time has been characterized as

$$
\begin{aligned}
& 194 \text { Afzelius, op. cit., p. } 91 . \\
& 195 \text { Afzelius, op. cit., p. } 25 .
\end{aligned}
$$


being "experienced and wise" in matters of the vorld, especially with regard to Empire and "ready to conquer" naw: lands in the name of the Queen. 196 This era of British rule was dominant, aggressive, and vain; and it reflected itself in the attitudes towards the black inhabitants of Sierra Leone and Liberia. Where the colonists' main concerns were the lack of suitable entertainment and the paucity of their accustomed fools, the "natives" were dismissed in the following cursory nanner, provjded by one Colonel Ballantyne in 1870.

I use the term (savage) advisediy, because I wish to call things by their right name. The savage Is a savage, and in my experience among the natives of different parts of the earth. I have never met with what is styled the "Noble Savage," nor even heard of a genuine specimen, except in cases when individuals have embraced the civilizing Gospel. Let me not be misunderstood. I have no sympathy whatever with those who regard "niggers" as an inferior race of ignoble men, who are only fit for the benefic of the highly exalted, to be killed or turned into beasts of burden. But on the other hand, I have little sympathy, and no agreement. with those who, forgetting, apparently, that this red-Katir is in truth a savage, would treat him as if he were already a Christian and try to do him every possible good, and chiefly, to bring his soul in contact with the savior, is our simple duty, but to trust him is no part of oux duty. It is worse than folly because it defeats our philanthropic views and prolongs his debasement. Who would trust a thief; or a liar, or a murderer? The whole Kafir notion, root and branch, is a huge thief, an inveterate 1iar, and a wholesale murderer. 197

The feelings that the "native" was an "uncontroilabie savage" resulted in records which are punctuated with numerous exclanation points, completing remarks on the "intrinsic inferiority of the native." Solwe records were not so caustic as others, but the general tone of them was decidedly of

${ }^{196}$ Roy Lewis ata Yvonne Foy, The British in Africa (New York: Weidenfield and Nicolson, 1971), p. 28.

${ }^{197}$ Lewis and Foy, op. cit., p. 29. 
a superior making judgments on an inferior. Such views reflected a notion which predominated the latter half of the nineteenth century in the form of "pseudo-Darwinism," which assigned a "childlike quality to the innate$1 y$ mentally deficient African," who required the moorage and steerage of the whites. 198 The "inferiority" of the blacks was alleged to be reflected in tlieir polygamy, nakadness, the $\mathrm{r}$ body odcr (which observation the the blacks made about the whites), their "fetishism" and witchcraft, and. their barbarities such as poison ordeals. 199 inether the motive driving the adventurers, travelers, and traders was the excitement of discovery or the desire for profits in a far-off land of riches, it was the sense of destiny on the part of the Victcrian British to endure the legendary White Man's Burden.

Assuming the "innate inferiority and savagery of the black" iniabitants of Sierra Leone and Liberia, the manner in which the reporters during this period would described the sasswood ordeal should be considered. In general, most writers were concerned more with the appearance of things than their operation, and any items which were strange were summarily dismissed as non-Christian and therefore evil. In keeping with such a eategorization, the records from this period only describe the ordeal in superlatives and in the barest of detail and without toc much of the benefit of explanations for their purfose in the society. Explorers, adventurers, travelers, and others were not tco concerned with the conversion of the inhabitants of Sierra Leone and Liberia ${ }^{198}$ Kingsley, op. cit., p. ix.
${ }^{199}$ Lewls and Foy, op. cit., p. 69. 
because their interests were more in trade and adventure and fame. Where they condenined the practices, such as. the sasswood ordeal, which they encountered there, there was little attempt rade to change this behavior. The effect of this group of Victorian British may be regarded as minimal to the practice of the sasswcod ordeal.

The effect of the missionary on the African appears to be more germane to the present survey. The missionary, or so-called humanitarian, approach to the study of the people of West Africa, long influential in that continent as well as other areas of the Empire, originated in the late eighteenth century as a kind of over-reaction to and atonement for the slave trade and the Protestant ideas which had supported it. 200 In keeplng with the notion of "pseudo-Darwinism" described above, all the evils of the sociaty--pcverty, disease, fears--vere blamed on what they considered to be the evil, false religion; and the missionaries arrived In a flurry of religious fervor to rectify the situation and to show the residents the "True and Guiding Light."201. Where the missionary was the one who stayed the longest with the indigens, knew his language and some of his custon, he also was the one who tried the most to alter the status quo. Missionary work became a conscicus attack on the traditional African society itself. Conversion was not limited to religious beliefs and practices, but also to clothing, habits of behavior, table inanners, artistic endeavors, and other aspects.

The recalcitrance on the part of the African to be converted ${ }^{200}$ Lewis and Foy, op. cit., p. 57. ${ }^{201}$ Ibid. 
to Christian belief, other than paying a token "jip service" by attending church, may be explained by two facts. Fixst, the missionaries themseives appeared to have engaged in the very witchcraft and magic that they condemed in the fact that they crossed the sees and introduced such charms as lighters and such magjcal tools as carieras. It was difficult to convert the "virgin, if darkened minds, avajting the message of redemption and salvation," 202 if the white hinself engaged in practices just as "senseless and barbarian" to the black. This point of cultural relativn ism appears to have been one never really appreciated, considered, or practiced by most missionaries.

The second factor of the inhabitants' unresponsiveness to the proselyzation may be explained in terms of the resiliance of their religious beliefs to change. Since these aspects formed such an integral part of the culture with its moral rules, it may be stated that the rissionaries" efforts to upset this balance were in vain. The missionaries were particulariy appalled by the belief system which functioned in relation to "evil" as manifested by idolatrous "fetishes" and the belief in witchcraft, and not in relation to "goodness and God." The basic iebenssicht of a people cannot be so readily and crastically altered as the missionaries had hoped.

An exarple of the missionary's attitude to the practices of the inhabitants of this region may be seen by quoting briefly the records of one missichary, George Thompson, who served in Sierra Leone in the mid-nineteenth centluy. His report and comments may be regarded as be202 Ibid. 
ing fairly typical. The reference is not to the sasswood ordeal in

particular, but to the general bejlefs of the traditional African.

What ideas a poor, Ignorant African has of such idols or fetishes, and the virtue of their vorshipping them, it is difficult to find out. We cannot get low enough in their deep depths of degradation to get a clear understanding of it; indeed their notions seem to be a corfused mass of superstitious fancies, that they cannot definiteiy and clearly express. 203

and

... Though they "know God," they do rot pray to Him, or worship Him, or study, desire, and seek to please Him, but follow their own evil hearts; and for their known wickedness, for not obeying the light they have, they must be condemned ... Even of the heather may it be truthfuliy said, "Ye knew your duty but ye did tt not." 204

With regard to more specific "acts of cruelty:" Thompson has this to say.

To the foregoing (description of the cruelty of the Poro sacrifice) add the almost innumerable victims which are continually being burned to death for witchcraft, etc., and what vast multitudes of innocent human beings are yearly sacrificed on the altar of heathendom, to superstition! It is awful to think of it, and yet the stern and horrid reality exists while I write and you read. May the bjessed Gospel soon do away with these savage cruelties: 205

The intent and effect of the missionary on the practice of the sasswood ordeal may be described. Since the missionary's work was principa11y religious conversion, and since the ordeal and oaths belong to that classification of items resistent to change, one can deduce that the sasswood crdeal would remain constant in underlying ldeology and functions, if not in its manifestations. The missionary attack was not

$$
\begin{aligned}
& 203_{\text {Thompson, op. cit., p. } 162 .} \\
& 204 \text { Thompson, op. cit., p. } 163 . \\
& 205_{\text {Thompson, op. cit., p. } 424 .}
\end{aligned}
$$


against the ordeal specifically, though it was condemed for its inbunane crueliy (so they thought), but they did attempt to change the religious structure of a practice which would require dissolving the beliefs in witcheraft and the spiritual efficacy of "drinking fetish" and oathswearing. Wrile the African way have attended the church services held by the missionaries and changed the name of their nature gods to those of the saints and of theix creator to God, there was no change in the structure of their belief system. The historical record may serve as witness to the fact that the sasswood ordeal did not change in either form or function, especially in the case of the hinterland tribes. Where some groups did drop the crdeal because of legal, government pressure, the oath-swearing was retained and substituted for the ordeal.

\section{Urbanization}

It is significant to note that industrialization, which had served as a boon to the slave trade in that slaves were exchanged for manufactured goods, $^{206}$ and urbanization also affected the sasswood ordeal oniy slightly in form and not at all in function. Instigation of the Frotectorate and 1ts laws forbidding ordeals ${ }^{207}$ seems to have resulted in tine underground activity of the sasswood ordeal and the continuance of oathswearing. Oath-swearing persisted because it was required in Sierra Leonean and Liberian national courts and proved efficacious because of the belief held in them, that is, that they would seek out the fuilt in a person if it were there.

$$
\begin{aligned}
& { }^{206} \text { Lewis and Foy, op. cit. } \\
& 207 \text { Erics, op. clt. }
\end{aligned}
$$


At least two reports have been made of the contemporary use of the sasswood ordeal in urban centers, which is unique to the records offered for the practice. In 1960 Gerard Periot reported that President Tubman of Liberia had used the pofson ordeai to decide an official case In 1947 in the village of Koulous. ${ }^{208}$ In addition, hans Himmelheber in 1958 reported the contempcrary use of the sasswood ordeal in Monrovia, Iiberia, so that the use was not limited historically to only the hinterland regions. 209 In the case cited by Himmelheber, the person employing the ordeal was a Dutchman whose knowledge of the ordeal's psychojogical efficacy in the view of those tribes using it resulted in true selfIncrimination by those accused of theft, in this modern case. The point with both these cases is that up to the present time and in urban areas, where one would expect the influence of the modern world to be the greatest, the ordeal is still used, though by the writ of the countries' constitutions, they are $i l$ legal. ${ }^{210}$ The specific case of theft has altered the use of the ordeal somewhat, but its basic function of ascertaining guilt and the psychological uses to which it was put have apparently not changed, in that the fear inspired in the accused is the means of the ordeals' and the oaths' operation. One nay assume that the educational function described in Chapter III has survived.

\footnotetext{
${ }^{208}$ G. Periot, Night of the Tall Trees (Eondon: Frederick Muller, 1960).

${ }^{209}$ H. Wimnelheber, Die Dan: Ein Pauernvolik im westafrikan Urwald (Stuttgart: Kon1hanmer VerIag, 1958).

210 price, op. cit.
} 
CHAPTER V

SUMMARY AND CONCLUSIONS 
CHAPTER V

SUMMART AND CONCLUSIONS

One purpose of the thesis has been to more clearly define the meaning, characteristics, and purposes of the sasswood ordeal as well as oath-swearing among the West Atlantic tribes of Africa. By surveying the historical sources over the past six hundred years, it was hoped that a composite picture of the ordeal would appear and provide a broader understanding of this ritual in terms of the legal and religious life of the societies studied. In addition, since the approach and techniques used were historical, evidence of the persistence of these practices was sought. In order to deiermine the success with which these goals were met, a brief summary of the findings is necessary in forming the conclusions.

\section{SUMMARY: THE SASSWOOD ORDEAL}

The sasswood ordeal is a form of technological divination which is utilized by those practicing it to solve problems, especially regarding crimes, which cannot be solved because there are too few facts. Alternatively, the ordeal is 1 sed to decide cases, especially of witchcraft and adultery, where the moral judges in the soctety, usually the zo, do not wish to be held personally responsible for having made the decisions. This "alienation effect" is achieved by the use of Poro masks among the Liberian tribes, and in addition, by the fact that in the viewers' eyes, 
these ordeais are manifested as the judgments of the supernatural and not of human agents. Such a divine juggment is thought to be more stringent and impressive and, therefore, the lesson taught more deeply engrained in the individual. The sasswood ordeal owes its speclal efficacy to the fact that the drinking of draughts, such as the sasswood concoction, is an especially potent way of testing one's veracity and "good faith," in that the individual driniking the infusion becomes mystlcally infused with the divinatory power itself, which will find the truth of the crime--whether the accused is innocent or guilty--within the person and make the accused vomit if he is innocent.

There are several functions postulated for the sasswood ordeal and oath-swearing other than the obvious legal-religious guilt-determining mechanism, whose counterparts in western society may be seen in the 1le-detector test and in swearing on the Bible.

It was noted that through the action of accusations, as rather straight-forward projections of jealousy and enmity on the part of the accuser, certain latent, and sometimes less-than-latent, hostilities are released, which might otherwise disrupt the society's moral and social equilibrium. This was seen as the sucial unifying effect and serves to re-achieve cultural balance by the ritual purgative demonstrated in both accusations and the subsequent oatins and ordeals. The ordeal is especially significant in this regard in that a single individual, or "scapegoat," becomes the focus of these tensions and hostilities.

In that the wealthy and powerful were usually the ones accused of witchcraft and therefore subjected to the sasswood ordeal, the function 
as an equalizer or Ievelar or social status within the society may also be considered. By being fined or by the family of the accused, shouid be die in the ordeal or afterwards as punishment for his guilt, relinquishing all their goods and in the extreme becoming slaves, wealth in the society is reaistributed and the former powerful ones are reduced to a less-than-mighty status. This would serve to retain another kind of status quo, in which the menters of the society were roughly equal in. power and wealth. In addition, it was thought that during the seventeenth, eighteenth, and nineteenth centuries these functions were especially important because there was an apparent increase in the number of accusations and subsequent ordeals for the purpose of acquiring more slaves for the markets of Europe and the New World. Such a fact may be regarded as temporary functional change in the practice of the ordeal due to outside economic pressure.

Finally, the sasswocd ordeal was seen in connection with the Poro secret society; and in this sense, two functions were deduced. First, because the $\underline{z c}$ were reported to possess the most powerful "medicine" in the societies and the only "official" medicine to be used in determining guflt or innocence (ge du), the sasswocd ordeal would seen to serve to reaffirm the "poifcing" function of the Porc and especially the superlority of the zo in this regard. Second, the Poro, in performing the crdeal, acts as an educational body in inculcating the norms and rules of: the soclety by the memonic device of the sassivood ordeal. By this is meant that through the pain and the violent and enotional performance of the ordeal, the rules of the society, which were transgressed and necessitated the ordeal, are further incuicatad into the minds of the 
audjence observing the practice. This may be more succinctly phrased "setcing an exampe" for the rest of the society so that "it will not have to happen to me."

II. CONCLUSIONS: ' ETHNOHTSTORIOGRAPHIC PROBLEMS

In surveying the historical evidence, there were two principal problems, other than the ones of ethrohistoriography mentioned in the Introduction, which have placed limitations on the drawing of specific conclusions regarding the conservatism of the practice of the ordeail and substantiation of those conclusions. First, the historical record was piecemeal in the descriptions of the ordeal. By this is meant that no one tribe was reported continuously through time with respect to the ordeal, so that it became difficult to accurately assess the degree of change with respect to this trait-complex for the whole area. For example, it was not possible that evidence of a change in form reported for the Temne in the eighteenth century be extrapolated as evidence for all groups in all time periods of the West Atlantic cluster. To attempt to do so would give disproportions.

Second, the references nade to the ordeal in the various tribes were tangential and incomplete, in that the reporters usually merely stated that she practice existed and very rarely did the authors go into significant detail regarding the specific elements of the practice or any form of interprecation $2 s$ to its functions. In short, no one has made the complex the special focus of a study. The fact that the record had to be pieced together in such a composite fashion as a result of the above-mentioned deficit in the historical record meant that any suppo- 
sitions of clilture change weuld necessarily renain, for the most part. conjecture. Rather than the descriptions of the ordeel proper, the con texts became more smportant for the detection of functional persistence in the practice in that these would represent slgnificant changes. Keeping in mind these problems which were encountered, the historical influences described in Chapter IV will be aiscussed.

IXI. CONCLUSIONS: PERSISTEITE AND CHANGE IN THE SASSWOOD ORDEAL Islam

Islamic influence on the ordeal would be limited to those tribes which had had prolonged contact with that religion, and these were the Mende, Temne, Yalunka, Vai, Susu, Grebo, Kru, and to a lesser extent the Limba. Islam had already in its religious repertoire divinatory practices such as sand divination (kaesant) and the casting of stones (angbere), and swearing of oaths on the Koran (angbaibe1) would be congruent with the ordeai and oath-swearing already extant in the abovementioned tribes. The change would be in substance and not in kind, so that the legal-religious divinatory function would remain the same. In addition, the written code of the Sharia, providing a system of codified rules, would mean that the mnemonic effect of the ordeal, as described above, would no longer be required for the learning and emotion al inculcation of the laws of the society.: The Sharia was "revealed law" and because it, too, was divinely ordajned, would retain religious sanctions for moral conduct. In conclusion, it may be said that the shift was frou the "violent" orieals to more routine forms of divination which rould eerve the purpose of deciding linknown or unknowabie issues, 
but which apparenty implied the discolution of the social stacus equal.. izing functions, in that there was a prearige factor attached to the adoption of Islam. The educational, or mnemonic, flinctions were assumed by the Shariz.

\section{Slavery}

Slavery was selected as a possible influence on the practice of ordeals and oath-swearing because it was correctly supposed that the socletal upset incurred by the removal of members from the society at home and the chaos caused by the disruption of families and ways of izfit in the colonies would result in an increased reliance on religious practices in the manner of social pathology: "cosmic thumb-sucking." of particular importance in this case would be the function of tensionreliever and as a social unifier in times of emotional stress. It was noted that the idea of drinking the concoction which held magic powers of divining the truth within an Individual remained and its frequency apparently increased. In this instance, the form changed from drinking an actually poisonous, purgative concoction to drinking a symbolically purgative brew of graveyard dust, whose efficacy would have to be purely psychological. The function remained the same, however. It is not possible to conciude at this time whether the educational function remained, for nowhere was there reported any audience observing the ritual who would be required for the educational purpose. Probably the moral lessons remained, but one sannot be sure.

Note has already been made of the increase of the practice of the sasswood ordeal in connection with the greater demand for slaves, which may be cailec an economic function. 
Western Europe: Explorers and Misstonacies

The western Europeans, in particuiar the British missionaries, made the greatest concentrated effort to change the sasswood ordeal, because It was part of the iegal-rejtgious beliefs which were contrary to the Christian "virtues" which they were promulgating as a means of atonement for their own guilt of the slaving period. The alternatives offered to the inhabitants of Sierra Leone and Liberia-going to church, praying to a god dissimilar from their own system of nature spirits and especially the denial of witchcraft as a viable life-force--were basically against the grain of indigenous belief. These alternatives were unsatisfactory at an emotional and Ideological level to the indigens in that they did not solve their problems and daily dilemmas. Their system of causality based on the pervasiveness of ancestral spirits, and non-ancestral spirits, allowed for direct justice meted out by the supernatural and the obedience to the system of "bland, unemotional" written laws did not prove a satisfactory alternative to them. In keeping with the discussion of the resiliance of religion, laws, and such practices as the sasswood ordeal and oath-swearing which intermesh the two ideas, these items of "the essentials of ideological securfty" are noted to "die hard" unless faced with equally satisfying alternatives, which the missionaries and government officials simply would not and could not provide. Because they viewed these practices as "cruel and savage," the sasswood ordeal was made illegal by about the turn of the twentieth century, but oathswearing was allowed to continue because it was considered to be harmless and also to be efficacious because of the inhabttants' belief in them. However, regardless of the ban on the sasswood ordeal by the Protectorate 
governments, the practice has continued to the present (1.e., 1967) 211 in the hinterlands and is ferformed "undexground," indicating the persigtence of the supernaturaliy sanctioned trials and judgments made through the action of the poison.

\section{Urbanization}

If anything, the effect of the urbanization and more extensive encroachment of the western world, replete with its economic demands ("jobs," success, a moneyed econony) and its social requisites (monogamy, bilaterality, feminism, education) may be supposed to have increased the practice of sasswood ordeals and oath-swearing in their functions of relieving social and moral tensions at a societal level. Mention has been made of the fact that divination, as a means of knowing the unknown and deciding 1ssues so important that the judgments should not be the responsibility of "mere mortals," is tenacious and adaptable to various changing circumstances. $^{212}$ Howells has stated that the divinatory acts and arts are one of the most persistent of all religious activities. ${ }^{213}$ since the new pressures of the modern world mentioned would result in greater personal indecision, problems and tensions, it may be concluded that ordeals and oath-swearing will probably persist at least as long as the pressures do. It might even be likely that they would increase because the job and moneyed econoluy may well result in a greater proportion of have's over have-not's, which may, in turn, produce jealousies and enmity to cause the greater incidence, though c1.andestine, of accusations of witcheraft.

${ }^{211}$ Fischer, op. cit.

212 Dorjann, op. cit., p. 7.

213 W. Howeils: The Heathens (New York: Ancihor Books, 1962), p. 66. 
and the subsequent ordeal by sasswood. The function of "soctal leveling" would thereby possibly increase. The educational purpose for inculcating group morals and zules will also be expected to be emphasized if there continues to develop nativistic movements in returning to the old customs in reaction to the wite putting pressure on the black to adopt the former's cultural mores.

The situation may eventually arise where the oath-ordeal complex assumes the status of a cultural survival, that is, an item of cultural behavior which has remained beyond its imnediate "usefulness" to the society and is retained for "traditional" reasons. It has aiready been noted, for instance, that the political and legal authority of the Poro has diminished through the years. 214 If the vestern courts of law become more persuasive in their ideology, the directly determinative and retributive purposes of the crdeal may deciine. However, as an emotional. and sanctified technique for edicating its members in moral laws, the ordeal-oath ccuplex would retain its utility. No evidence has been found to support such a furctional shift at this tire, but future investigations may provide data ior such a claim of cultural survival as a part of nativistic movements or as a revival in traditions.

\section{CONCIUSIONS}

In conclusion, through the diachronic study of the sasswood ordeal and catis arong the tribes of the West Atlantic cluster, a further exploration and explanation of these specific practices has been provided. 214 Hariey, op. cit. 
They are seen as being essentialy conservative practices in that they are a recessary part of the legal and reigions life of the West Atlantic tribes and the basic structure of ordeale and oaths has not changed sitice it was first directly mentioned by llawkins in 1560 to the present day. During the history of the practices, there heve beer certain formal. changes, such as swearing on the Koran rather to the individual nonancestral spirits, and the intensification of the use of the ordeal in matters of theft in New horld slave communities; but essentially the form, contexts, and functions of the sasswocd ordeal and oath-swearing have remained constant through time, reflecting the adaptability of the complex in response to varying pressures and dilemmas. In addition, it has been demonstrated that these purposes will remain in the future due to increasing, though different, pressures from western societies to conform to their value systems. If they chenge at ali, it will be as one of the last elements of the culture to perish, ior the resolution of indecision and the desire and the necessity to know the unknown are part of that amorphous quality, human nature, and no amount of Christian. gospel and scientific "common sense" can solve that intrinsic quirk in man. 


\section{A SELECTED BIBLIOGRAPHY}

Adams, John. Remarks or the Country Extending from Cape Palmas. London: Thomas Neison, Ltd.: Printers, 1910.

Afzelius, Adam. Siexra Leone Journal 1795-1796. Uppsala, Sweden: Studia Ethnographica Upsaliensa, XXVII, 1967.

Alldridge, Thomas J. The Sherbro and Its Hinterland. New York: MacMillan and Company, 1901.

Allot, A.N. Essays in African Law. London: Butterworth Press, 1960.

Allot, A.N. Judiclal and Legal Systems in Africa. London: Butterworth Press, 1962 .

Anderson, J.N.D. "Relationship between Islamic and Customary Law In Africa" Journal of African Administration, XII (1969), pp. 228-234.

Armstrong, J.N.D. "West African Inquest" Anerican Anthropologist, LVI (1954), pp. 1051-1069.

Aronson, Sidney H. "Obstacles to the Approchment between Histoxy and Sociology: A Sociologist's View" Interdisciplinary Relacionships in the Social Sciences. Ed. Muzafer Sherif and Caroiyn W. Sherif. Chicago: Aldine, 1969.

Barzun, Jacques and Henry F. Graff. The Modern Researcher. New York: Harcourt, Brace, and Worid, 1957.

Baumann, H. and D. Westemann. Les Peuples et Les Clvilizations de L'Afrique suivi de Les Langlies et L Education. Trans. M. L. Homburger. Paris: Payot. 1967.

Beattie, John. "Ritual and Social Change" Mar, I (1966), pp. 60-74.

Beatty, K.J. Yuman Yevpards: An Account ce the Trials of Human Leopards Before the SpeciaI Comission Court. London: Hugh Rees, Led., 1915.

Blake, John Wiliam. Europeans in West Africa 1450-1560. London: Hakluyt Scciety, 1942 .

Blake, W.0. The History of Slavery and the Slave Trade. Columbia: $\mathrm{J}$. and $\mathrm{H}$. Militer Pubishers, 1858. 
Blassingame, John $w$. The Siave Community. New York: Oxford Universicy Press, 1972.

Boahen, A. Topics in West African History. Iondon: Longmans, 1966.

Bridge, Horatio. Journal of an African Cruiser 1845. London: Dawsons of Pall Ma11, 1968.

Brittan, Harriet. Everyday Life in Africa. London: Puarey and Russel1s, 1860 .

Brooke, N. J. "Native Ccurts in Sierra Leone" Journal of African Administration, VI (1954), pp. 185-193.

Brooks, George. "Salem Merchant ir Cape Dalmas, Liberia, in 1840 " Essex Institute Historical Collection, LXIVVIII (1962), pp. 161-174.

Burns, Francis. "Trial by Ordeal" Anthropos, $\nabla$ (1910), p. 808.

Burton, Sir Richard. Two Trips to Gorilla tand and the Cataracts of the Congo. London: Jaw, Marston, Law and Searle, 1876.

Burton, Sir Richard. Wanderings in West Africa, Volumes I and II. London: Tinsley Brothers, 1863.

Blttikofer, Johan. Reisebilder aus Liberia. Leiden: E. J. Brill Verlag, 1890.

Catteral1, Helen. Judicial Cases Concerning American Slavery and the Negro. Washington, D. C.: Carnegie Institution, 1932.

Clébert, Jean-Paul. The Gypsjes. Trans. Charles Duff. New York: Penguin Eooks, 1967 .

Corry, Joseph. Observations on the hindwara Coast of Africa 1805-1806. London: Cass Fublishers, 1968.

Creel, J. Iuke. Folk Tales of Liberia. Minneapolis: T. S. Denison and Compary, 1950 .

Crone, G. R. The Voyages of Cadomosto 1455. London: Hakluyt Society, 1937.

Curtin, Philitip. Africe Remenbered, Madison: Jniversity of Wisconsin Press, $196 \%$.

Curtin, Phillp. Inzge of Alrica. Madson: University of Wisconsin Press, 1964.

Cuvelier, Gascon. "Les Preuves Itidiciares dans le Territoire de Jadotville" Anthropos, XuXVII-Xi (1942), po. 254-308; pp. 497-505. 
Dapper, Olfcrt. Umbethndic3e uni Eigen 1icle Jeschreibung von Afrika una dener dazu gebdrighn k̈bigreicher üad Landschafter. Ansterdan: Jacob von teers: 1620 .

Daviasori, Basil. A History of West Africa. Garden City: Anchor Books, 1966.

Davies, 01iver. West Africa before the Eurppeans: Archeology and Prehistory. London: Methem Press, $196 !$.

Dorjahn, Vernon. "Some Aspects of Temine bivination" Slerra Leone Bulletin of Religion, IV (1962), pp. 1-9.

Eliade, Mircea: The Forge and the Crucjb1e: London: Rider and Company, 1962.

Flias, T. 0. Ghana and Sierra Leone: The Development of Their Laws and. Constitution. London: Stevens and Sons, Ltd., 1962.

E111s, A. B. The Land of the Fetish 1857. "Westport, Connecticut: Negro University Press, 1970.

Evans-Pritchard, E. E. "Consulting the Poison Oracle anong the Azande" Reader in Comparative Rieligion. Ea. William Jessa and Evon Yogt. Second Edition. New York: Harper and Row, 1965.

Evans-Pritchard, E. E. "Witchcraft Explains Unfortunate Events" Reader in Comparative Religion. Ed. Wiliiam Lessa and Evon Vogt. Second Edition. New York: Harper and kow, 1965.

Fage, John. A History of West Afxica. London: Cambridge University Press, 1969.

Farb, Peter. Man's Rise to Civilization As Shown by the Indians of North Anerica from Primeval Times to the Coming of the Industrial State. New York: Avon Eooks, 1958.

Fashole-Luke, Edward. "The Themes of Myths: Their Status and Right Appraisal in West African Keligion" Sieria Leone Bulletin of Religion, VII (1965), p. 3304.

Feldstein, Stanley. Once a S1ave. New Yor: Morrow Press, 1971.

FieId, M, T. Religion and Medicine of the Ga People. London: 1937.

Finnegan, Ruth. Limba Stories and Story Telling. London: Oxford University Press, 1967.

Finnegan, Ruth. "Oral Tradition" History and Theory, IX (1970), p. 155. 
Fimegan, Ruth. Survey of che Limba Pecple of Northern Sierra Leone. London: Her Majesty's Stationer's Office, 1965.

Finnegan, Ruth. "Swears among the Llmba" Sierta Leone Dulletin of Religion, VI (1964), PI. 8-26.

Fischer, Eberhard. "Erzhhlgut der westlichen Dan im Liberia" Anthropos, IXII (1967), pp. 686-744.

Fortes, Meyer. African Political Systems: London: International African Institute, 1940.

Foster, George, May Diaz and Jack Poiter. Feasant Society. Boston: Little, Brown, and Company, 1967.

Furnas, J. C. Goodbye to Incle Tom. iNerv York: Sloane and Assoctates, 1956.

Fyfe, Christopher. "Baptist Churches in Siexza Leone" Sierra Leone Bulletin of Religion, $V$ (1363), pp. 55-61.

Fyfe, Christopher. Sierca Leone Inheritance. Icndon: Oxford University Press, 1964.

Gabel, Creighton. "Toward an Interdisciplinaty Method for African Culture History" Reconstructing African History. Ed. Creighton Gabel and N. R. Benuett. Boston: Boston University Press, 1957.

Gausseau, Pierre-Dominique. Forêt Sacrea: Magie et Rites Sécrets des Tomas. Paris: Editions Albin Michel, 1954.

Gibbs, James I. "Poro Values and Courtroom Procedures in a Kpeile Courtroom" Southwestern Journal of Anthropology, XVIII (1962), pp. 3410350。

Gibbs, James L. "The Kpelle of Liberia" The Peoples of Africa. Ed. James L. Gibbs. New York: Holt, Rinehart, and Winston, 1955.

Glucknar, Max. Polftics, Law, and Ritual in Tribal Society. New York: Mentor jooks, 1965 .

Gordon, J. "African Law and the Historian" Journel of Arrican History, VIII (1967), p. 335 .

Hall, H. U. The Sherbro of Sierra Teone. Philadelphia: University of Pennsylvania Press, 1933.

Harley, George W. Masis and Agents of Social Control in Nörtheastern Liberia. Papers of the Peabody Museum of Anerican Archaeology and Etnnology, XXXII. Cambridge: Harvard Untversity Press, 1947. 
Harley, George. Notes on the poro of Livexia. Eapers of the Peabody Museum of American Archaelogy and Etinology, XIX. Cambridge: Haryard University Fress, 1941.

Harley, George, Native African kiedicine. New York: Cass Publishers, 1970.

Harris, Marvin. The Rise of Anthropological Theory. New York: Crowel1 Press, 1968.

Himeiheber, Hans. Aura Poku. Eisenach, FDR: Rich Rd:h Verlag, 1951.

Himelheber, Hans and UIrike Himmelheber. Die Dan: Ein Bauernüolk in westafrikan Urwald, Ergebnis drier vUlkerkindicher Expeditionen Im Hinterlande Liberias, 1949-1950, 1952-1953, 1955-1956.

Stuttgart: Kohlhammer Verlag, 1958.

Hoebel, E. Adarnson. The Law of Primitive Man. Cambridge: Harvard University Press, 1967 .

Howe11s, William. The Heathens: Primitive lian and His ReIigion. New York: Doubleday-Anchor, 1952.

liuber, Hugo. "Ritual Oaths as Instruments of Coercion and Self-Defense among the Adangme of Ghana" Africa, XXIX (1959), pp. 41-49.

Hutchinson, Thomas J. Impressions of Western Africa. London: Longman, Brown, Green, Longmans, and Roberts, 1858 .

Ingham, Right Peverend E. G. Sierza Leone after a Hundred Years.

London: Seeley and Company, 1894.

Jablow, Aita. An Anthology of Wast African Folklore, New York: Thanes and Hudson, 1962 .

Johnston, Sir Harry. Liberia. Two volumes, New York: Dodd, Mead, and Company, 1906.

Kaigh, Frederick. Witchcraft and Magic of Africa. London: Richard Lesley and Company, itd., 1947.

Keesing, Felix, Cuitual Anthropology. New York: liolt, Rinehart, and Winston, $19 \overline{58 .}$

Keesing, Felix. The Ethnohistory of Northern Luzon. Palo Aito: Stanford University Press, 1962 .

Kingsley, Mary H. Travels in West Africa 1862-3900. Iondon: MacMillan and Company, 1897.

Kingsley, Mary h. West African Studies. Third Edjtion. London: MacMilian and Company, 1899. 
Kirk-Greene, A, H. M. "On Swearing" Afyice, XXV (1955), p. 43.

Kluckhohn, Clyde. "Myth and Kitual" Readsr in Comparative Religion. Second Edition. FA. William Lassa and Evon Vogt. New York: Harper and Row, 1965.

Kup, A. P. "Jesuit and Capuchin Missions of the Sevenceentin Century" Sierra Leone Bulietin of Raligion, $V$ (1963), pp. 27--34.

Lessa, William and Evon Vogt. Reader in Comparative ReIigion. Second Edition. New York: Harper and Row, 1965.

Lewis, Herbert S. "Ethnology and African Culture History" Reconstructirg African Cuiture History. Ed. Creighton Gabel and iv. R. Bennett. Boston: Boston University Press, 1967.

Lewis, Roy. Sierra Leone: A Modern Portrait. London: Her Majesty's Stationer's office, 1954.

Lewis, Roy and Yvonne Foy. The British in Africa. New York: Weidenfield and Nicolson, 1971.

Litt.le, Kenneth. "The Mende of Sierra Leone" African Ideas of God. Ed. Edwin Smith. Ejinburgh: House Press, 1950.

Little, Kenneth. The Mende of Sierra Leone. London: Routledge and Kegan Pau1, 1954.

Iittle, Kenneth. "The Mende of Sierra Leone" African Worlds. Ed. DaryIl Forde. London: International African Institute, 1954.

Lloyd, P. C. Africa in Social Change. New York: Penguin Bcoks, 19 .

Luke, Barry Charles. A Bibliography of Sierra Leone. Westport, Connecticut: Negro Universities Press, 1969.

McAllistar, Agnes. A Lone Woman in Africa. New York: Hunt and Eaton, 1906.

McCali, Daniel F. Africa in Time Perspective. Foston: Boston University Press, 1.964.

McCulloch, $K$. The Peoples of the Sierra Ieone Frotectorate. London: Internationa]. African Institute, 1945 .

Matr, Lucy P. "Witcheraft cis a Frobien in the Study of Religion" Eahiers d'Etude Africsines, iV (1964), PF. 335-348.

Malinowski, Bronislaw. Crime and Custom in Savage Socisty. New York: harcourt, Brace, and Wurid, 1926. 
Malinowski, Bronislav. Magic, Science, and Feligion. Nev York: Doubleday-Anchor, 1954.

Messenger, John C. "RoIe of Proverbs in a Nigerian Judictal. Systen" Southwestern journal of Anthropology, YY7 (1959), PP. 64-73.

Migeod, F. M. H. A View of Sierra Lsone. London: Kegan Paul, 1926.

Milligan, Robert $\mathrm{F}$. The Jungle Folk of Afrect. London: Flening $\mathrm{n}$. Reve11, Co., $190 \overline{0}$.

Mills, Lady Dorothy. Through Liveria. London: Duckworth Press, 1926.

Moore, Omar Khayam. "Divination: A New Perspective" Peader in Comparative Religion. Ed. Willian Lessa and Evon Vogt. New York: Harper and Row, 1965.'

Morris, Herbert. Guilt and Shame. Belmont; California: Wadsworth Press, 1971.

Murdock, George Peter. Africa: Its People and Their Culture History. New Yoris: McGraw-Hil1, 1959.

Nade1, S. F. "Reason and Unreason in African Law" Africa, XXVI (1956), p. 150 .

Nader, Laura, Klaus F. Koch, and Bruce Cox, "The Ethnography of Law: A Bibliographic Survey" Current Anthropology, VII (1966), pp. $267 f$.

Ndanema, Isaac. "The Rationale of Mende Swears" Sierra Leone Bulletin of Religion, VI (1964), pp. 21-25.

Norbeck, Edward. "African Rituals of Conf1ict" American Anthropologist, IXV (1963), P. 1254 .

Park, George" $k$. "Divination and Its Social Contexts" Reader in Comparative Religion. Ed. William Lessa and Evon Vogt. New York: Harper and Row, 1965.

Parrinder, Geoffrey. West African Religion. London: Epworth Fress, 1949.

Parrinder, Geoffrey. West Afxican Psychology: Comparative Study of Psychology and Religious Thought. London: Butterworth Press, 1951.

Parsons, Robert T. "Kono Religion and Preparation for Adult Life" Sierra Leone Bulletiz. cf Reigion, III (1961), pp. 11-16.

Parsons, Robert $T$. "Kono Religion and Adult Cxises" Sierra Leone Bulletir of Religion: IV (1962), Po. $5 i-53$.

Parson, Robert T. Religion in an Afrlcar Society. Leiden: E. J. Bri11. Verlag, 1964 . 
Pauline, Denise. Les Gene du Riz. Paris: Libraire Pion, 1954.

Periot, Gerard. Night of Ta11. Trees: Account of a Journey of 1500 Miles on Foot J'hrough the Liberian Junjle. London: Trederick Muller, Ltd., 1960.

Piers, Gerhart and Milton "P." Singer. Shame and Guilt: A Psychoanalytic and A Cultural study.: Springfield, Inlinois: Charles C. Thomas, 1953.

Pitt, David C. Use of Historical Sources in Anthropology and Sociology. New York: Holt, Rinehart, and Winston, 1972.

Pospis11, Leopold. The Tlature of Law. Eugene, Oregon: University of Oregon M. A. Thesis, 1952 .

Price, J. H. Political Institutions of West Africa. London: Hutchinsoni Educational Press, $196 \%$.

Radcliffe-Brown, A. R. Structure and Function in Primitive Society. New York: The Free Press, 1965.

Radir, Pau1. The Method and Theory of Ethnology. New York: McGrawHil1, 1933.

Ranger, T. O. Emerging Themes of African History. Dar es Salaam: East African Publishing House, 1968.

Rawick, George. The American Slave from Sundown to Sun-up. Westport, Connecticut: Greenwood Press, 1972.

Renner, Dr. W. "Native Poison: West Africa" Journal of the African Society, III (1904), pp. 99-102.

Roberts, J. M. "Oaths, Autonomic Ordeals, and Power" American Anthrepologist, IXVII (1.965), p. 186.

Rubin, Morton. Plantation County. New Haven: College and Iniversity Press, 1951.

Schwab, George. Tribes of the Liberian Hinteriand: Peabody Expedition of 1947. Cambridge: Harvard University Press, 1947.

Simaons, Dorald. "Efık Divination, Ordeals, and Proverbs" Southwestere Journa? of Arthropoiogy, XII (1956), p. 223.

Social Science Research Council. The Social Sciences in Historical Study. New York, 1954.

Solomon, Marvin D. and Warreñ I. D'Azevedo. A General Bibliperaphy. of the Repubiic of ibbria. Evanston: Northwestern University Press, 1962 . 
Strong, Richatd. The Afriean republic of Liberia: The Harvard Expeditson ô 1926-1927. Canbridge: Harvard Jiniversity Press, 1930 .

Sturtevant, Wiliam. "Arthropology, Mistory; and Ethnohistoxy" EthnonisLozy, XiTI (1966), pp. 1-52.

Swanson, Guy. The Birth of the Gods. Anv Arbor: Ann Arbor Paperibacks, 1966.

Tannenbaum, Frank. S1ave and Citizen: The Negro in the Anerjeas. Nery York: Alfred Knopf; 1947.

Thomas, Northccte $W$. The Anthropology of Sterca Leone: Law and Custom of the Timne and Othes Tribes. London: harriscn and Sons, 1916.

Thompson, George. The Paim Land, or West Africa. London: Dawsons of Pall ilall; $18 \overline{58 .}$

Irimingham, J. Spencer and Chriscopher Fyfe. "Early Expansion of Islan in Sierra Leone" Sierra Leone Bulletin ố Religion, II (1960), pp. $33-40$.

Trimingham, J. Spencer. The Influence of Islam on Africa. New York: Frederick Praeger, 1968 .

Vansina, Jan. "Ethnohistory in Afrisa" Etinoilstory, IX (1952), pp. 126136.

Varsina, Jan, "Oral Tradition as History in Africa" Daedalus, C (1971), p. 442 .

Vansina, Jan, R. Mauny, and I. V. Thomas (Ed.). The Historian in Tropi-cal Africa. London: Cxford University Press, 1964.

Vernon-Jackson, Hugh. West African Folktales. London: University of London Press, $195 \overline{8}$.

Viard, Capitaine René. Les Guerès: Peuple de 1a Forêt. Paris: Scoiétie d'Editions Géographique, Maritimes, et Coloniales, 1934.

Wallace, Anthony $r$. C. Religion: An Anthropological View. New York: Randow House, 1966.

Warner, Esther Sietmann. "A Iiberian Ordeol" Studies in the Anthropology of Conflict. Ed. YauI Bohannon. Garden City: Natural History Press, 1967 .

Willans, R. If. K. "The Konnon People" Journai of the African Society, VIII (1909), pp. 130-144. 
Wilson, Charles Moxrow. Liberia. Pew York: Sloane Associates, 1947.

Wilson, Reverend J. Leightor, Western Africa: Its History, Condition, and Prospects. New York: Harper Brothers, 1.856 .

Winterbottom, Thomas. in Account of the Native Africans (1.803).

Two Volumes. London: Cass Publishers, 1969.

Wylie, Renneth. "Fthnohistory and Eolitical Change" Journal of Modern African studies, VIII (1970), pp. 113-122. 
APPEINDIX A

A. SUMARE OI THE EXPLCRERS TO SIERRA LEONE AND LIBERIA, WITY SPECTAL REFERENCE TO THE PRACTICE OF TUE SASSWCOD ORDEAL

\begin{tabular}{|c|c|c|c|c|}
\hline EXPLORER & DATE & I'RIBES & $\begin{array}{l}\text { SASSWOOD } \\
\text { ORDEAL }\end{array}$ & OATHS \\
\hline Cadomosto & 1455 & Nolof, Serex & $x(?)$ & \\
\hline Valentin Fernandes & $1506-1510$ & Bulöes (Bullum?) & & $\mathrm{x}$ \\
\hline John Hawkins & 1560 & $?$ & & $x$ \\
\hline A. A. De Almada & 1594 & Sapes, Fulas & & $\mathrm{x}$ \\
\hline O1fert Dapper & 1620 & $\begin{array}{l}\text { Mandingo } \\
\text { Bellimo (Dullom?) }\end{array}$ & & $\mathrm{X}$ \\
\hline Thomas Corker & 1684 & Sherbro & $\mathrm{x}$ & $x(?)$ \\
\hline John Matthews & 1788 & $\begin{array}{l}\text { Sherbro, Susu, } \\
\text { Mandingoes }\end{array}$ & & $x(?)$ \\
\hline Zacharay Macaulay & 1793,1796 & Sherbro, Bullom & $\mathrm{x}$ & $\mathrm{x}$ \\
\hline Adam Afzeilus & $1795-1796$ & Temne, Bullom & $\mathrm{x}$ & $\mathrm{x}$ \\
\hline Thomas Winterbottom & 1803 & $\begin{array}{l}\text { Fulas, Mandirigoes, } \\
\text { Xru, Temne }\end{array}$ & $\mathrm{X}$ & $\mathrm{X}$ \\
\hline Joseph Corry & $1805-1806$ & $\begin{array}{l}\text { Mandingoes, Kru, } \\
\text { Temne (?) }\end{array}$ & $\bar{x}$ & $\mathrm{x}$ \\
\hline Capn. E. Harrington & 1840 & Teme & $\mathrm{X}$ & \\
\hline Horatio Bridge & $1843-1844$ & Kru, Temne (?) & $\mathrm{x}$ & $\mathrm{X}$ \\
\hline Rev. C.W. Wilson & 1856 & $\begin{array}{l}\text { Temne, Grebo, } \\
\text { Susu }\end{array}$ & $x$ & $\mathrm{X}(?)$ \\
\hline Thomas Hutchinson & 1858 & Kru, Temne & $\bar{x}$ & $\mathrm{x}$ \\
\hline
\end{tabular}


EXPLORER

DATE

1858

George Thompson

Farriet Brittan

1860

s1r Richard Burton

A. B. Ellis

Johan Bütt:ikofier

Mary Kingsiey

R. H. K. Willans

1901

1901

T. J. AlIdridge

Agnes McAllister

Sir Harry Johnston

Kobert Milligan

K. J. Beatty ..

N. W. Thomas

Ledy Dorothy Mills

Richard Strong

F. M. H. Migeod

1926

1934

Cap̧n. René Viard

H. U. $\operatorname{lia} I 1$
1906

1905

1908

1915

1916

1923

$1926-1927$
TKIBES
SASSWOOD ORDEAT.

OATHS

(n)

-

Sherbro, Susu,

$x(?)$

$\mathrm{x}$

Mende, Kru

xru, Grebo

$\mathrm{x}$

Kru, Temne, Kissi, X

Grebo, Mardingo

Sherbro, Rossu (?), X (?)

Jenne

Vai

$\mathbf{X}$

$x(?)$

$1890-1900$

Teme, Galjita,

Sherbro, Kru

X

x

Kono

$\mathrm{X}$

Sherbro, Krim,

$\mathrm{Kru}$.

$x$

$X(?)$

$\mathrm{X}$

Va1, Gio, Mano,

Sikcn, Mandingo,

Kru, Kpwesi

$\mathrm{x} \quad \mathrm{x}$

Bullom, Mende $x$

Temne

$\mathrm{X}$

$\mathrm{X}$

Temne, Susu,

Limba.

$\mathrm{x}$

$\mathrm{X}$

Vai, Grebo

$x$

$\mathrm{X}$

Kpwesi, Eul10x,

Kru, "Gibis,".

Mende, Grebo,

"Burjowali".

y.

X

Susti, Limba,

Terine

$\mathrm{x}$

$\mathrm{X}$

Guerës

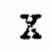

Shembro, Eutlon

$\mathrm{x}$

$\mathrm{X}$ 


\begin{tabular}{|c|c|c|c|c|}
\hline EXPLORER & DATE & TKIBES & $\begin{array}{l}\text { SASSWOOD } \\
\text { OQDEAE }\end{array}$ & OATI \\
\hline M. NeCulloch & $\begin{array}{l}\text { N.D. } \\
\text { Ca. } 1945\end{array}$ & $\begin{array}{l}\text { Mence, Loko, } \\
\text { Temne, Limba, } \\
\text { Vai, Yelunka, } \\
\text { Susu, Koranko }\end{array}$ & $\mathrm{X}(?)$ & $\mathrm{x}$ \\
\hline Charles wilson & 1947 & Mano & $x$ & \\
\hline George Schweb & 1947 & $\begin{array}{l}\text { Mano, Gio, Vai, } \\
\text { Haif-Grebo, Grebo }\end{array}$ & $x$ & $\mathrm{x}$ \\
\hline George Harjey & 1947 & $\begin{array}{l}\text { Vai, Nano, Kpwesi, } \\
\text { Kpeile, Dan }\end{array}$ & $x$ & $\mathrm{x}$ \\
\hline Kenneth Little & 1949 & Mende & & $\mathrm{x}$ \\
\hline Esther S. Warner & 1949 & $\therefore$ & $\mathrm{x}$ & $\mathrm{x}$ \\
\hline Gausseau & 1958 & Toma & $\mathrm{x}(?)$ & \\
\hline Denise Paulme & 1954 & Kissi & $\dddot{\mathrm{n}}$ & $\mathrm{x}$ \\
\hline H. Hismelheber & 1958 & Dan & $x$ & $\mathrm{x}$ \\
\hline Gerard Periot & 1959 & $\begin{array}{l}\text { Bassa } \\
\text { "Liberians" }\end{array}$ & $\mathrm{x}$ & $\mathrm{x}$ \\
\hline Vernon Dorjahn & 1959 & Tenne & $\mathrm{x}$ & $\mathrm{x}$ \\
\hline Ruth Finnegan & $1960-1961$ & Limba & $x$ & $\tilde{z}$ \\
\hline Kenneth Parsons & 1961 & Kono & & $\mathrm{x}$ \\
\hline Eberhard Fischer & 1967 & Dan & $\mathrm{x}$ & $\mathrm{x}$ \\
\hline
\end{tabular}


APPETNDIX 3

Reproduced fron Adan Afzelius, Stersa I-eone Journai 1795-1796 (Uppsala, Sweden: Studia Ethiographica Uppsaliensa, XXVII, 1967), pp. 24-30.

\section{A REDWATER TRIAC}

It was about $100^{\prime}$ ciock a.m. when we arrived, and then almost everything was ready for the trial; but they could not begin it beifore the arrival of Sr. Domingo, as a principal persoil in tinis business. Near 11 o'clock arrived at lask Sir. Domingo. And as every thing besides was now ready for the trial, they ware going to begin it directly. But before I commence to give a description of it, I shall state the case,

When that great Parlaver was held hera in September, I believe, 1793, on account of Erince Naimbanna's death, there were Natives and their Chiefs assenbied not only from Sierra Leone, but also from all neighboring Countries rourd atout--Duxing this time and second day after they had been assembled, there was found fir the roorning a cead body in a canoe in susan's bay. Eeing wistea it was found to have a blow on the head, and cossequentiy it was commonly bejteved, that the man had been killed by sone body unknomi--But as it was proved, that he had been drunk the preceding night, it was not at all improbable, that he might have fallen down in the canoe and killed himself. 
But be this as it may, the young Doningo, to whon the dead inan belonged, accused another from Bujiamshore of faving kilied hin. They had been seen together the preceding night, as weli as some cther Natives, drinking and rankling. But as the accuser particulariy if a headman in a capital crime is not obliged to alledge any reason, the real motive of the accusation always remains a profound secret. He nay do it upon $\bar{z}$ very good foundation, but also only out of spite and ennity. And the accused have no other change or method of clearing himself, than to submit to drink the red water.

This is the case here. The poor man from Bullamshore was accused of having killed one of itttle Domingo's people, and little Domingo ras not satisfied without his drinking of red water. But it seemed as he had directly taken his refuge to Jemmy Queen and Robin Dick, for they were evidently his defenders. He was now living in the town of the latter and under his protection, and the former had already let him secretly drink the red water to see, whether he could stand the public trial. This is however common, and scarcely any body drinks publicly the red water who has not done it privately before amongst his friends.

As Kobin Dick and Jemny Queen were on the side of the accused, so great and little Domingo were against him and the latter acquiesced entirely in the superior talents and uncomon efforts of his Brother to get the man guilty.

And no wonder, that they make their best endeavours on both sides; for when the watter is cariied so far as to the trial, it is an affair of great consecuense to both parties. For on one side there is a life to be lost or saved, and even if the man should not dite by drinking of 
the vater, if there should be combted the least fault, or he rot able to stand the trial according to the full ygour of this savage custom, he will efther be doomed to slaveiy, he and his whole family, or pay three slaves to the accuser.

On the other side there is the prosecutor, who if the defendent gces through the trial in its full axtent according to the laws of the country as they call it, will be obliged to pay a siave, who, it seems, ought in justice to belong to the accused, but whose value his defenders always share between themseives.

As it is necessary that the red water should be taken on an empty stomach, watch is always given to the accused the night previous to the trial, in order to prevent hin from eating anything, that may promote throwing off the water by vomiting.

At our arrival to Prince George's, the delinquent and his body Guard, consisting of about 8 or 10 , chiefly young men, were seated in the Parlaver house, and no other person was then allowed to go there. They were all dressed in a decent manner, but the accused was stark naked, except a narrow cloth or girdle round the waist.

As soon as $\mathrm{Sr}$. Domingo had arrived, this body of people arose, on a slgnal or order given by Prince George, going a11 in the wood, and one of them carried the delinquent on his back. The cause of their retreat, I suppose, was to make necessary preparations and to put everything in readiness and order on the place of the triai-min the mean time there was a great deal of consultation between the Chiefs, particularly those who were interested in the issue--And at last they ware all called to come in Prince George's houee by Domingo, who read to them, being assembled 
and seated dow on the ground, long evesch, containing ... the statement of the case and the indictment. This bejng inisted, there vas fired a gur, as a stgnal that the trial was to conoence and that wa shoulo 211 retire to the place, were $t$ was to be ield ... Having gone abort 2 half a mile through the roods, we arrived to a lugar, where ve found the delinquent and his attendents before us, on tive left hand side or towaras the west, for we came in to the place iron abcut the south, We were ordered to keep to the right hand side or towards the East ... Arongst us and next to us were the principal chiefs seated, as Sr. Doringo, Robin Dick, etc.--Behind us ard towards the $5 . \mathrm{E}$. were a great crowd o: the lower people, and farther towards the $S$., on the right hand of the entrance to the lugar, were standing all the women and the smallex children, and the very entrance was occupied by some of the inferior chiefaon the North or towarcis the sea were no people at a.ll. Jemmy Queen and Prince George had placed thenselves within the crowd, at some distance from one another--This whole assemb1y was thus arranged in the form of a cirkle, which was open on the N. Sida.

The accused stood before his Guard, very near to it, and turned his face towards the south... At the right hand side were erected two stakes at a distance of four feet, and of these that towards the south was much higher than the other. These two stakes were besides jolned by two cross-stakes, one above the other and on different stdes of the erect stakes, or in that manner, that they formes a sort of seat, the upper cross stake being a support to the back, and the lower one a pjace to sit on. 
Behind this so cajled seat or towards the west, and the southern side of it, the ground was peatly covered with Plantain leaves, on which were placed the bark, that was to be used, a large brass kettle, filled with clear water, a straight new cut stake, a whisk or wisp with four short thick horizontal teeth of the same length and in the form of a half cirkel, and a larger foloon or Wooden mortar. These implements seemed all. very neat and clean and were a1l put on the south side of the seat;--Before the seat were some new cut sticks all laid across, on which the delinquent was standing, so that he did not touch the ground.

The effects and consequences of drinking the water ara, according to the ideas and custom of the Natives as foliows: If the drinker by vomfing throws up all the colàh or rice he has taken on an einpty stomach, before the sunrise the following morning on much more if he does It during the very trial then is he innocent and publicly declared not guilty of the crime for which he was accused. But if he should die on the spot, or by purging get rid of the colàh or rice, then is he believed and proclaimed Guilty. In the former case hils whole family and sometimes alsc his nearest relations are sentenced and dragged inco slavery; and in the latter he is to join ther himself and to share their miserable fate.

As soon as the man has vomited any part of the Colìh, he is released for the present and allowed to leave the place cf Trial, tho' always accompanied by his guard or some other persons, who narrowly watch him, for he is not yet considered as innocent. He must by vomiting get rid of ali the Colah he has taken, before the next morning, and that without having eny other evacuation during the same time, neither 
plssing nor purging. But should he faif in any of these circumstances, that is to say, if before the stated tirie neither all the colah shouid come up, or he should be obliged to 60 to $5 t 00 i$ or under necessity of pissing, then he is considered Guilty and dooned to slavery. But in this case he can redeem himself by procuring three other slaves which he had not right or sanction to do, if ali the Colah had remained witinin the body or been purged out, and no part by romiting thrown away.

Amongst the Guard of the delinquent there is always one confident person selected as Headnan, who superintends all the preparations beiore the Trial and the making of the red nater, who inakes some speeches ani who takes care, that every thing goes on decently and according to custom during the whole Trial. The person who was now chosen seemed to be a middle aged man grave and steady, with shavea head. I never sars him before. He opened the proceedings and spoke some words, as soon as we were all assembled and seated. I understood, he reproached the Headimen and Chiefs for having retarded the Trial and had kept him, the watch and the delinquent waiting too long a time: Jemmy Queen anc Robin Dick. gave him an änimated answer in few words. They seemed to speak with Indignation.

This watter being settled it was ordered, that the Red water should be made--The Yeadman who had the direction of this business, arose and spoke to him and to one of his attendents or of the guard, who directly took up the bark intended for the preparation of the water, and shewed it to the assembled nultitude, turing it on all sides and in ail directiuns for a good while. There weze three pieces or caies of 1 , nearly orbicular, ainost as large as comon places \& all of equal size. The 
outer or rough bark had been taken off and the colkes afterwards scraped, washed, and cleaned in a ritee mannex.

In this state they were shewn to the surrounding crowd, which being done, they were untied and taken out of the bleft of the stick, in order as they sat in it, and laid fown on the Barana Laves. The man who was ordered to prepare the red-water tock ther, after having freviously washed his hands, these bark cakes, one after the other and holding them over the wooden mortar, broke them into pieces, which were afterwards beaten by a wooden pestle into as sma11 parts as the moisture cf the bark. would permit of, for it was not dried, but quite fresh, taken. from the tree that very morning.

The bark being surficiently pounded, it was taken out of the Poioon and put into the Brass Kettle above mentioned, which I was assured did not contain any thing pure pure and clean water.

Here it remained for a while in order, as I supposed, that all virtue, power and strength contained in the bark, should be drawn out and comnunicated to the water--In the meantime several transactions took place, which 'I shall relate in orcier as they were performed. In the ilrst flace the Headman of the Guard on the making of the red water rose and advancing towards the delinquant stopped opposite to him at a very $1 i \pm t l e$ distarce. Here he held a long speech to firn, which he seemed to deliver with a cool steady ard deliberate mind, without that affected zeal, that noisy vehemence and those ridiculous gestures, which disgraced the performances of the Other Orators. I did not understand a word of what he said. But I should iniagine, that he repeated the indictment, stated the case with ali its circumstances, and 
admonished the accused not to drink the water, if he was guilty, but exhorted hiri on the contrary to shew himself an fiero, in case he was Innocent, and so on--Before he began his speech, he took out of his pocket a red Colahh, I believe a whole one, and having taken a bite of it himself, which he shewed and swallowed, he gave the rest to the delinquent who also shewed and swallowed it--As being so chief he was not permitted to use the sacred Parlaver-broom or brush--During the whole speech; there was a man of the guard standing behind the delinquant, and turning his back towards the speaker's face and the back of the delinquant, finished every sentence of the speaker with a word, that signifies the same as our Amen or it is true.

As soon as the Speaker had ended his discourse, he withdrew and sat doin on his former place ... But then began the delinquant hinself to speak, in order as I was told, to clear himself of the crime iaid to his charge, and to prove his innocence, which would appear more evidentiy by his drinking the red-water without the least hesitation, as he was convinced, it would not dc him the least injury ... The assembly seened not displeased with his defence, tho' pretty long, they Iistened to witin attention and fiatience.

After tie had finished, the man, who had befora pounded the bark and put into the Brass Rettle, began to take it up out of the water ... --He took the pounded bark and squeezed it with all his inight between the hands, in order that all the water contained in it. might run out in the kettle, and at the same time he rolled it into oblong balls as large as a fist, which he laid down on the Banana Leaves, one near the other. And this operation he continued till there was to bark left in the water. 
Then tre took the whisk and beat it uninteruptedly, till it began to lather so much, that I saw the froth above the edges of the kettie. This circumstance made me guite astounded, for I had not expected to find such a virtue in the redvater bark, which I had litherto only considered as enetic, and powerful cathartic. But being at the same time of a saponaceous nature seens rather inccnsistent, for the latte: quality comonly destroys the former two. The casemust therefore be this. Either operates the red waier only as to its quanticy taken and that differently according to different constitutions; or do they secretiy put some emetic into the water. But as everyching seens to be administered very fairly and in so open a manner, that any body may discover, whether there is committed any roguish trick, or not; I can not conceive, how It might be possibly dore, if the emetic substance should rot be put beforehand fito the mortar or the clean water contained in the brass Kettle, these being the orly two things I could not examine myself nor did I see any body else do tt.--But be this as it may, It is ar undeniable fact, that the red water produces a lather like soap, and that the effect or consequence of drinking it, is vomiting or purging.

The water, which a person accused of a capital arime, is obliged to drink according to the African custcm, is called fed water cver the whole coast, at least hereabouts and to the northward. From this denomination one would naturally expect to find efther the bark or the water or both of a red colour; but no such thing, fir though the baxk has soretimes and in some places a faint tincture of a pale red, you won ${ }^{3} t$ observe the least of $i$ it in the water. And therafore $T$. do not understand what thint have been the crigin and cause with improper nathe. 
As soon as the culprit had finishexi his speech, there vas adduced by Beaver Tom some Grigris contained in a ieather bag, and which I believe consisted chiefly of soine new cut and fresh twigs of certain plants. This bag being laid upon the ground before the accused at some distanca from him, Beaver performed a religious or rathar supersticious ceremony in consacrating the Grigris by strewing some flour of Indian corn on tinem and in a circular form on both sides at a great distance, and at the sane time delivering a long speech or speaking continualiy during the whole operation.

Grigris so sonsecrated are considered more holy than before and by them the Cuiprits are to swear, whose oaths are then regarded as micre binding than otharwise; just in the same way as the Bible is used in taking caths by the Christian. When Beaver Tom had performed his orfice, the Culprit began to speak, swearing by his consecrated Grigris, that he would speak truths and was willing to undergo the trial by drinking the red-water, as he knew, that it could not hurt him being innocent.

The water being cleaned from all bark and properly teaten by the wisk, some of the Chiefs and several other persons arose and went to see, whether the water was properly made, pure and genuine, as it: was now considered as ready made. And after them having unanimously testified their approbation of it, the Headman of the Cuiprits Guard arose to consecrate chis water by making a speech over it ... (and) he foljowed a usual custom in striking the Kettle a certain number of times with each of the sticks.

Having gone through al1 the sticks and finished his speech, the Chiefs gave signal, every thing, now befing ready for the beginning of the 
most essential and most serious part of this water ordeal. The Director spoke then to one of the attendants to adrinister the water to the culprit, who had hitherto stcod upon some cross stfeke immoveable turning his face towards the South or S.S.E., as I have chserved above; but now when he was going to begin the drinking, he turved and set himself up in the towermost cross stick between the two posts, which I have nentioned abcye was put togethex in some shape of a chair, at least so that he could use the lower cross stick as a seat and have support for the back of the upper one. He now turned hij face towards the East or the E.N.E.

Being thus seated, the man, who was appointed to administer the water, and who now for a beginning was the same that had prepared it, took a large Calabash measuring about a pint fjilled it quite full with the prepared water, leaving only some few drops on the bottom which the administrator of it in order that the ordeal should be performed fairiy, foured out on the ground, so openly and slowly that every man present could see, that the Calabash was quite empty. He then filied another, and so on uninteruptedly, till he had consumed five, then he wished for some respite, which being gxanted, he directiy began to puke and threw up a great deal of water, after some vain efforts and violent convulsive motions of the muscles of the Belly, which were evidently seen from without, and must have tortured him internally with excruciating pains.

After a short pause he desired the main to give him some more watar and then he drank five full Calabashes again, but not so fast and uninteruptedly as the five first. For he stopped now a little at each o: every seconc Calabash, reaching and vomiting very often more or less, commonly with muscular convulstons in the stomach. 
most essential and most serious part of this water ordeal. The Director spoke then to one of the attendants to administer the water to the culprit, who had hitherto stcod vpon sone cross sticki immoveable turning his face towards the South or S.S.E., as I have chserved above; but now when he was going to begin the drinking, he moved and set himself up in the towermost cross stick between the two posts, shich I have nentioned above was put togethex in some shape of a chair, at lesst so that he could use the lower cross stick as a seat and have support for the back of the upper one. He now turned his face towards the East or the E.N.E.

Being thus seated, the man, who was sppointed to administer the water, and who now for a beginning was the same that had prepared it, took a large Calabash measuring about a pint filled it quite full with the prepared water, leaving only some few drops on the bottom which the administrator of it in order that the ordeal should be performed fairiy, foured out on the ground, so openly and slowly that evexy man present could see, that the Calabash was quite empty. He then filied another, and so on uninteruptedly, till he had consumed five, then he wished for some respite, which being gxanted, he directiy began to puke and threw up a great deal of water, after some vain efforts and violent convulsive motions of the muscles of the Belly, which were evidently seen from without, and must have tortured him internally with excruciating pains.

After a short pause he desired the man to give him some more water and then he drank five full Calabashes again, but not so fast and uninteruptedly as the five first. For he stopped now a little at each o: every second Calabash, reaching and vomiting very often more or less, commonly with muscular convulstons in the stomach. 
... sr. Domingo arose, went to the place, took the whisk and began to speak in an animated voics. He seemed to enoloy all his endeavour, ali art and cunning, ali possible afforts, all strength of arguments and reasoning, shortly all mears anc devices his natural skill and acquired abiltries could afford or furaish him with, to put the Culprit in feax and niake him despondent, and to convince tie assembled multitude, that: he was guilty of the capital crime he was accused of. He therefore not being satisfied with the Timany (Temne) Grigris, or thinking them not powerful enough, let his own, or Portuguese Grigris, be brought forward and put near to the former; and spoke over them alternatively for a good while. (The Culprit) drank now and then a Calabash of redwater, and when he had taken the 10 th, he vomited abundantly throwing up a great quantity of water and at last there cane out some thing which at the distance I sat seemed on the ground where it fell to resemble white froth, and on my asking what it was, I got for an answer that it was a part of the half Cola he had been eating before the commencement of the trial, that he now began to shew his innocence and that he consequentiy could hope to go through his trial without any detrimental accident.

As soon as this part of the Cola was tirown up, many of the assembled people, and principally all the chief men, arose and went to lock at it, several of them at the same time uttering some few words which I was told implied, that tho' it was the true colah he had vomited still it was not a sufficient portion to shew that degree of innocence, that he could yat be released, but he must first drink some more water. And according1y he set about it again ... and at the end of it threw ip a greater portion of Coläh, which being observed, Jemny Queen stood up and 
spoke some few woras to him, purporting as $I$. inderstood, that he had now shown enough of his innocenca to be at scine ijberty, and that he could therefore now descend from his sear, go home and take some rest.

Then came an old woman, and spoke to the Culprit in a very decent and emphatic manner. Her speech was rather short, which being finished there came two young women running out froin the fenale crowd towards the Culprit, accusing him for bad behavior to the sex in general and theti jii particular as he had not ione his duty and given then full satisfaction, speaking rather indecently but in few wordsa: They had neither the whisk in the hand, nor did they seen to make so much ceremony of it as the other speakers. They were only forced according to the usual custom to confess openly their secret opinion abcut the culprit, for at such occastons every body present man or woman who hes any thing against the person who stands his trial, must come forward and fublicly accuse him of 1t. This is the law of the Country.

During these speeches of the women, the Culprit took two or three calabashes of water. It did not do any effect before they had retirad, and then he vomited very violent $1 y$, and at last threw up a great portica of Colàn, than he did the first time; which bairg observed, several went to look at $i t$, but Jemmy Queen approaching nearer, spoke some faw words to the culpxit, purporting as $I$ understood, that he had now shown enough of his innocence to be set at some liberty, and that he could therefore now descend from his seat, go home and take scne rest.

Accordingly, he descended, shaked ninself as a wet foul stretched. out all his ilimbs and very unexpectedly began in a moment to run as fast. 
as he ever could, towards Prince George's town, which when the people saw, they gave up a terriole sinout, and ran after him es if they had been mad, particularly the chiefs, who by their vioient endeavours, soon outstripped all the others and became the foremost, next to the culprit, keeping close to his heels, bellowing, roaring; howling all the while, till they reached their goal. We then found as before the trial, the women in one place or house, and the men dispeised about in several, walking or seated, silent or discoursing, and in the middle of then the Culprit in the same undress taking exercise by walking, runnjing, and jumping in order to prevent any bad effect of his drinking so nuch water and of other restraints curing the trial by sicting or standing imoveabie for so long a while.

I enquired what might be the meaning of their running so fast after. the Culpxit, their shrieking and crying, and what it now was to become of him, whether his trial was over and he sat at perfect liberty as found innocent, or whether he was to be kept in custody still longer, as having not yet fullfilled all the laws required--To the first I got for answer, that it was a custom of the Country to cry and run after a culprit to prevent hirn from any evacuation during the way, for in that case the trial should turn out abortive, and the culprit be found guilty in a certain degree--And as to his present situation, they said, he was only released from the hardest or wost difficult part of the tiral, that he may have the opportunity of taking some rest anö getting a necessary relaxation, but he was still in some sort of confinement, and they were to watch him narrowly till daylight and the following morning, in order that they should see themselves and so be able to convirce others, that 
he had really vomited up the whole colàh before that time without any other evacuation.

During the whole trial the assembled multitude benaved with greater propriety order and decorum, than I had expectel. Every one set quite st111 and attentive on what was going forward very seldom any body spoke or made the smallest noise but who had a right and observed his die time ... The people who set or stood in semicircles confabulated also together rather too loud and sometimes too buch. And we Europeans were in this regard as bad as any body else. 